\title{
Value Creation around Merger Waves: The Role of Managerial Compensation
}

\begin{abstract}
David Hillier ${ }^{\mathrm{a}}$, Patrick McColgan ${ }^{\mathrm{b}}$, Athanasios Tsekeris ${ }^{\mathrm{c}}$
Abstract

This paper examines the relation between executive compensation and value creation in merger waves. The sensitivity of CEO wealth to firm risk increases the likelihood of out-ofwave merger transactions but has no influence on in-wave merger frequency. CEOs with compensation linked to firm risk have better out-of-wave merger performance in comparison to in-wave mergers. We also present evidence that cross-sectional acquirer return dispersion is greater for in-wave acquisitions. Our results suggest that the underperformance of acquiring firms during merger waves can be attributed in part to ineffective compensation incentives, and appropriate managerial incentives can create value, particularly in non-wave periods.
\end{abstract}

JEL Classification: G31, G34, M12.

Keywords: Incentive Compensation, Vega, Delta, Merger Waves, Deal Performance.

a Strathclyde Business School, University of Strathclyde, Glasgow, G4 0GE, UK, Tel: 44141-548-3896,Email: david.hillier@strath.ac.uk

b Department of Accounting and Finance, University of Strathclyde, Glasgow, G4 0QU, UK, Tel: 44-141-548-3690, Email: patrick.mccolgan@strath.ac.uk

c Department of Accounting and Finance, Nottingham Trent University, Nottingham, NG1 4BU, UK, Tel: 44-115-848-2619, Email: athanasios.tsekeris@ntu.ac.uk (corresponding author)

Acknowledgments:

We thank Dimitris Andriosopoulos, Helen Bollaert, Jens Hagendorff, Andrew Marshall, Helena Pinto, Krishna Paudyal, Ronan Powell, Samer Semaan, an anonymous reviewer, and seminar participants at the 2015 International Accounting and Finance Doctoral Symposium (Ljubljana), 2016 British Accounting and Finance Association Scottish Area Group Conference (Glasgow), 2016 Financial Management Association Annual Meeting (Las Vegas), and the University of Bradford for helpful comments on earlier drafts of this paper. We also thank Martin Kemmitt for helpful research assistance. All errors remain our own.

Data availability statement:

This article has been accepted for publication and undergone full peer review but has not been through the copyediting, typesetting, pagination and proofreading process, which may lead to differences between this version and the Version of Record. Please cite this article as doi: $\underline{10.1111 / \mathrm{jbfa} .12419 .}$.

This article is protected by copyright. All rights reserved. 
The data that support the findings of this study are from subscription-based databases accessed through the University of Strathclyde. Restrictions apply to the availability of these data, which are available from the authors upon permission of the data providers.

\section{Introduction}

Merger waves cluster across time and industry (Moeller et al., 2005; Powell and Yawson, 2005). Mitchell and Mulherin (1996) propose that exogenous shocks to the cost and revenue structure of industries, including changes in technology and government regulations, drive merger waves. Shleifer and Vishny (2003) argue that waves are driven by the relative valuations of acquiring and target firms, and Garfinkel and Hankins (2011) show that merger activity is positively related to uncertainty about future cash flows. The value impact of merger waves is overwhelmingly negative with significant post-merger acquirer underperformance reported by many authors (Moeller et al., 2005; Bouwman et al., 2009).

Duchin and Schmidt (2013) find monitoring quality is poorer and information asymmetry higher during merger waves, which they attribute to weak acquirer corporate governance. In this paper, we directly test this hypothesis by asking whether CEO compensation incentives influence merger value creation around merger waves. Given its likely impact on CEO behavior (Croci and Petmezas, 2015; Lahlou and Navatte, 2017), remuneration incentive structure (Delta and Vega) will affect corporate merger performance, conditional on levels of merger activity.

In non-wave periods, when information asymmetries are low (Duchin and Schmidt, 2013), we predict that CEOs will respond positively to ex-ante compensation incentives that reward risky projects (Coles et al., 2006). For all merger decisions, managers receive private benefits of control including ex-post increases in CEO compensation (Goel and Thakor, 2010; Fu et al., 2013). During merger waves, weak monitoring conditions mean private 
benefits of control dominate ex-ante compensation incentives, and this will minimize the link between $\mathrm{CEO}$ incentives and a) the propensity to acquire, and b) acquiring firm performance.

Consistent with our expectations, we find that ex-ante CEO cash compensation is higher and pay-risk sensitivity, Vega, is lower for acquiring firm executives during merger waves compared to CEOs who lead out-of-wave mergers. We find no evidence that CEO compensation incentives are related to acquisition activity during merger waves, suggesting sub-optimal compensation design. In contrast, the relationship between Vega and the likelihood of initiating an acquisition is positive during out-of-wave periods. This is consistent with the view that higher pay-risk sensitivity reduces managerial risk aversion (Coles et al., 2006; Billett et al., 2010).

If in-wave acquisitions destroy value for the acquirer (e.g. Moeller et al., 2005), they should not be among the investment choices of CEOs whose interests are closely aligned to stockholders. We propose that the superior performance of out-of-wave deals can be partially explained by stronger compensation incentives and our empirical evidence supports this proposition. While Delta and Vega are positively related to short- and long-term stock price returns for out-of-wave acquisitions, no consistent relation is found for mergers initiated during a wave.

We also examine the standard deviation of cross-sectional post-acquisition abnormal returns for in-wave and out-wave acquiring firms. During merger waves, companies that make low quality acquisitions can more easily pool their performance with other acquiring firms and avoid investor scrutiny (Duchin and Schmidt, 2013). The larger number of merger events and performance variability leads to greater dispersion in post-acquisition returns (Yung et al., 2008). We find that firms engaging in merger activity during in-wave periods experience a higher dispersion of abnormal returns post-acquisition. In contrast, during outof-wave periods, high Vega CEOs make acquisition decisions characterized by a lower 
dispersion in cross-sectional post-acquisition returns. This supports our proposition that CEO compensation during out-of-wave periods incentivizes acquiring firm CEOs to avoid low quality acquisitions. On the other hand, we observe no difference in the dispersion of crosssectional post-acquisition returns between high and low incentive compensation CEOs during in-wave periods.

Our paper makes a number of contributions to the literature. We extend the findings of Duchin and Schmidt (2013), who show that adverse selection costs and inefficient monitoring of firm management can explain the acquiring firm underperformance during merger waves. This is driven, in part, by weaker compensation incentives provided to acquiring firm CEOs. Outside of merger waves, executives respond to pay-risk compensation incentives by making a larger number of acquisitions that create value for shareholders and display greater consistency in post-acquisition performance. During merger waves, compensation incentives are unrelated to deal performance and propensity to acquire.

Our results have implications for the optimal design of CEO compensation contracts. We show that the effectiveness of risk-seeking compensation incentives (see Coles et al., 2006; Cohen at al., 2013) is contingent on takeover market activity. Outside of merger waves, CEO risk-taking incentives increase the likelihood of managers undertaking mergers and the performance of acquiring firms, whereas such incentives are ineffective during merger waves. Our findings are robust to endogeneity testing (3SLS, PSM, predicted incentives) and a number of sub-sample analyses.

The paper is organized as follows. Section 2 surveys literature on merger waves, executive compensation and merger performance, and develops our empirical hypotheses. Section 3 outlines the construction of the sample and identification of merger waves. Section 4 presents our empirical results and Section 5 concludes. 


\section{Literature review and hypotheses development}

\subsection{Merger waves and acquiring firm performance}

The existence of merger waves is generally explained by industry shocks or stock market valuation (Mitchell and Mulherin, 1996; Andrade et al., 2001; Powell and Yawson, 2005). Harford (2005) argues that industry merger waves are caused by economic, regulatory and technological shocks under the condition that sufficient capital liquidity is available to accommodate acquisition transactions. Mergers can also occur in waves following deregulation of poorly performing industries (Ovtchinnikov, 2013). Shleifer and Vishny (2003) attribute merger clustering to stock market overvaluation. They argue that firms with overvalued equity are more likely to become acquirers with undervalued firms likely to be targets. Rhodes-Kropf and Viswanathan (2004) and Rhodes-Kropf et al. (2005) support these propositions.

Moeller et al. (2005) report higher short-term returns and significant long-run underperformance to in-wave acquiring firms; Ovtchinnikov (2013) provides evidence that bidder announcement returns are lower during merger waves that follow industry deregulation; and Duchin and Schmidt (2013) find no difference in short-term announcement returns for in-wave and out-of-wave acquiring firms, but significant long-term underperformance for acquisitions initiated during merger waves. Out-of-wave mergers increase long-run value for the acquiring firm (Bouwman et al., 2009) and acquirer underperformance is shown to be concentrated in mergers initiated later in a wave (Goel and Thakor, 2010).

\subsection{Executive compensation and corporate investment}

The ex-ante compensation incentives of top management can play an important role in acquisition decisions. Compensation contracts linked to stockholder wealth (Delta) and risk 
(Vega) may incentivize risk-averse CEOs to initiate mergers (Agrawal and Mandelker, 1987; Edmans and Gabaix, 2011). Both Cohen et al. (2013) and Croci and Petmezas (2015) report a positive relation between $V e g a$ and corporate investment.

We extend this literature and propose that the positive relation between Vega and acquisition propensity holds only outside of merger waves. Analysts and investors during merger waves are less able to differentiate between poor managerial decision-making and general market trends as the cause of inferior post-acquisition performance (Duchin and Schmidt, 2013). When firms are within a merger wave, pooling in a larger group of acquiring firms reduces risk aversion because managers are less likely to be held accountable for low quality merger decisions (Ross, 2004; Duchin and Schmidt, 2013). CEOs who are envious of competitor pay may drive in-wave deals because post-merger increases in CEO compensation outweigh the ex-ante incentives from existing compensation packages (Goel and Thakor, 2010). During merger waves, these effects dominate the positive relation between ex-ante compensation incentives and risky corporate investment documented in Coles et al. (2006) and Cohen et al. (2013). This leads to Hypothesis 1:

$H_{1}$ : There is a positive relation between ex-ante compensation incentives and the propensity to acquire only during an out-of-wave time period.

Incentive compensation can also improve the quality of managerial decision-making. Datta et al. (2001) and Minnick et al. (2011) find a positive relation between incentive compensation and firm performance surrounding merger decisions. Mergers initiated by highly incentivized managers are more likely to be motivated by synergies, growth opportunities and ultimately shareholder wealth maximization (Moeller et al., 2005; Bouwman et al., 2009).

This article is protected by copyright. All rights reserved. 
We propose that the previously documented relation between executive compensation incentives and post-acquisition performance will vary depending on the timing of a merger with respect to waves. Private benefits of control, expected increases in ex-post cash compensation, and a lower threat of detection following poor managerial decision-making will dominate ex-ante compensation incentives in driving managerial behavior during waves. Therefore, we expect the previously documented positive relation between incentive compensation and acquisition performance to be restricted to out-of-wave periods:

\section{$\mathrm{H}_{2}$ : There is a positive relation between ex-ante compensation incentives and merger} performance only during an out-of-wave time period.

Finally, acquisitions initiated during merger waves will be subject to greater information asymmetries relative to out-of-wave acquisitions (Duchin and Schmidt, 2013). In the context of IPOs, Yung et al. (2008) propose that information asymmetry and valuation uncertainty is associated with greater cross-sectional variation of stock price returns postlisting. Applying these arguments to merger waves, we expect greater dispersion in postacquisition stock price performance for acquisitions initiated during mergers waves.

During waves, transactions are more likely to be subject to competitive bidding, occur in concentrated time periods, and have a larger bid premium. Under such conditions, mangers undertaking low quality acquisition decisions are more easily able to pool with CEOs at other acquiring firms and avoid detection, which leads to more low quality mergers and a higher cross-sectional dispersion in post-acquisition stock price returns. In a standard agency framework, effective executive compensation design will induce more efficient due diligence. However, during merger wave periods, reduced monitoring and weaker corporate governance 
will moderate this negative relation between ex-ante compensation incentives and the dispersion of post-acquisition stock price returns. To examine this, we propose:

$H_{3}$ : There is a negative relation between ex-ante compensation incentives and the cross-sectional dispersion of post-acquisition abnormal returns only during an out-of-wave time period.

\section{Sample data}

\subsection{Sample construction}

We use SDC Platinum for all completed domestic mergers and acquisitions between January 1, 1993 and December 31, 2016, where the announcement and effective date is within our sample period. We follow Aktas et al. (2013) to identify merger transactions and add the following criteria: the disclosed deal value is at least $\$ 1$ million $^{1}$ and the bidding firm ${ }^{2}$ owns less than 50 percent of the target firm's stock six months prior to the acquisition announcement, and at least 50 percent of the target's stock after the transaction. The number of transactions that meet these criteria is $33,931 .^{3}$

We match these transactions to CEO compensation data from ExecuComp for the year preceding the merger. The starting year for data on mergers is 1993 because ExecuComp provides coverage of compensation data beginning in 1992. We also require merging firms to have stock price and accounting data available in CRSP and Compustat, respectively, for the year prior to the announcement. Applying these criteria produces a sample of 10,868 transactions by 2,389 firms with available accounting, stock price and compensation data.

\footnotetext{
${ }_{2}^{1}$ All dollar values are adjusted for inflation using the consumer price index and expressed in 2010 USD.

${ }^{2}$ Since all transactions in our sample are completed acquisitions, the terms 'acquirer' and 'bidder' or 'acquiring' and 'bidding' firm are used interchangeably.

${ }^{3}$ The actual number of transactions that meet these criteria is 34,533 but when the acquirer has undertaken more than one acquisition announcements on the same date, we keep only the deal with the highest value in order to maintain independence of observations. This results in 602 deals being removed from the sample.
} 
From this sample, we drop transactions where we cannot clearly identify the CEO of the acquiring company in ExecuComp. This results in a final combined sample of 10,684 transactions by 2,368 firms. In our empirical tests of $H_{2}$ and $H_{3}$ we use the combined sample to examine the relation between compensation incentives and both firm performance and stock price return dispersion surrounding M\&A transactions.

To test if incentive compensation increases the propensity to undertake M\&A transactions in $H_{1}$, we collect all ExecuComp firms with available CEO compensation data for the period 1992-2015. This produces an unbalanced panel data set of 44,673 firm-year observations for 3,711 unique firms. To determine whether these firms undertook M\&A in the subsequent year, we match firm-year observations in ExecuComp with the combined sample of 10,684 transactions above. We label this the ExecuComp sample and we use this sample to examine the relation between incentive compensation and propensity to undertake M\&A transactions.

\subsection{Identification of merger waves}

Following Harford (2005), we classify merger transactions as occurring inside or around merger waves. We identify merger waves within decades as follows: 1981-1990, 1991-2000, 2001-2010, and 2011-2016. Here, we use the full population of SDC Platinum transactions to generate waves and do not require data availability in ExecuComp and CRSP/Compustat. The sample is extended back to 1981 to avoid bias in the identification of merger wave patterns due to the unusually high merger activity in the 1990s, relative to preceding and subsequent periods.

If the acquirer and target are from the same industry, the transaction is counted only once towards the merger total for this industry. If the firms are from different industries, the transaction will count towards merger activity both for the industry of the bidder and the 
target. Industry groups are defined using the Fama and French (1997) 48 industry classification. Harford's (2005) classification allows for up to one wave per industry-decade. Potential waves consisting of fewer than 10 transactions are not considered actual waves.

This method identifies 94 waves across 40 industries, and these are presented in Appendix B. A total of 40 industries are identified with at least one wave, 31 industries with waves in at least two decades, 17 industries with waves in three decades, and six industries with waves in all four decades. For each wave, Appendix B reports the month that the 24month wave period started and the number of mergers during the wave. The largest wave is in the business services industry, which began in September 1998, and includes 1,494 completed deals. Harford (2005) identifies a similar wave for this industry at the same starting point. $^{4,5}$

Following the identification of merger waves, transactions in the combined and ExecuComp samples are recorded as taking place inside or around a wave. For the combined sample of acquisitions we define In-Wave as a dummy variable that takes the value of one if the acquirer or the target firm's industry is experiencing a merger wave at the point where the transaction is announced. For the ExecuComp sample that examines the propensity of firms to acquire we define In-Wave_Year as a dummy variable that takes the value of one if the sample firm operates in an industry that experiences a merger wave during the calendar year, and zero otherwise. ${ }^{6}$ Appendix A presents all variable definitions used in this paper.

\footnotetext{
${ }^{4}$ The Alcoholic Beverages and Tobacco Products industries do not have 10 or more acquisitions in any 24month period and the remaining six industries without a merger wave fail to fulfil the wave identification criteria following our simulation tests.

${ }^{5}$ The data for 1981-2010 is comparable to the findings of Duchin and Schmidt (2013) who report 77 merger waves in their sample period with 38 industries having at least one wave, 28 industries having two waves or more, and 11 industries having waves in all three decades. Using a similar method, Mavis et al. (2017) identify 65 merger waves between 2000 and 2014. Confining our analysis to the same time period, we identify 63 merger waves. Harford (2005) identifies fewer waves, but restricts his sample to transactions with a deal value above $\$ 50$ million.

${ }^{6}$ Note that In-Wave is a transaction-specific variable where, conditional on a merger taking place, the transaction is classified as occurring inside or outside of a wave period if either of the bidding or target firm
} 


\subsection{Summary statistics and variable definitions}

Table 1 reports summary statistics for all compensation and control variables used in the analysis. The results are presented in Panel A for the ExecuComp sample and Panel B for the combined sample. Comparing summary statistics in the two panels also highlights differences in compensation between firms that engage in merger activity and the universe of S\&P 1500 firms. CEO total compensation is the sum of salary, bonus, the fair value of new stock and option grants, and other components of executive pay for the year prior to the merger announcement. We follow Core and Guay (2002) and Coles et al. (2006) and examine the sensitivity of CEO wealth to stock price changes, Delta, and stock return volatility, Vega. ${ }^{7}$

For the ExecuComp sample in Panel A, the mean (median) Delta value is $\$ 886,000$ $(\$ 154,000)$, and the mean (median) value for Vega is $\$ 109,000$ (\$32,000). For the combined sample in Panel B the mean (median) Delta value is $\$ 1,875,000(\$ 210,000)$, and the mean (median) value of Vega is $\$ 167,000(\$ 40,000)$. The data in Panel A are comparable to those in Cohen et al. (2013) and Croci and Petmezas (2015). The higher average and median compensation values in Panel B reflect the expected positive relation between compensation incentives and corporate investment (Agrawal and Mandelker, 1987; Datta et al., 2001).

In our multivariate tests we control for a number of firm and deal characteristics that, according to prior literature, are associated with investment opportunities, propensity to acquire and acquisition performance (Powell and Stark, 2005; Powell and Yawson, 2007; Bi and Gregory, 2011). These include firm size (Moeller et al., 2004; Gorton et al., 2009), past performance (Jensen 1988; Harford, 1999), cash holdings (Harford, 1999; Faccio and

operate in an industry experiencing a wave. In-Wave_Year is a firm-year variable and classifies all firms in the ExecuComp sample according to whether their industry is experiencing a wave during the calendar year.

${ }^{7}$ We are grateful to Coles et al., (2006) for making their data on Delta and Vega to the end of 2010 publicly available. We update their calculations to the end of our sample period in 2015 using ExecuComp data. 
Masulis, 2005), leverage (Uysal, 2011), method of payment (Travlos, 1987, Golubov et al., 2012), listing status of target (Hansen and Lott, 1996; Fuller et al., 2002, Officer 2007), relative size (Asquith et al., 1983), book-to-market ratio (Rau and Vermaelen, 1998; Shleifer and Vishny, 2003), diversification (Morck et al., 1990; Cornett et al., 2003), speed of transaction (Golubov et al., 2012; Bick et al., 2017), and number of bidders (Alexandridis et al., 2010). Firm characteristics are measured at the financial year-end prior to the acquisition announcement, unless otherwise specified.

In addition, we control for the impact of industry-wide phenomena that may drive merger waves (Mitchell and Mulherin, 1996; Shleifer and Vishny, 2003; Rhodes-Kropf and Viswanathan, 2004; Harford, 2005; Powell and Yawson, 2005; Duchin and Schmidt, 2013). Overvaluation is a dummy variable that takes the value of one if the median market-to-book value of the firm's industry is higher than the industry's five-year moving average, and zero otherwise. Sales_Shock is defined as the difference between an industry's sales growth over a three-year window and the average sales growth of all industries based on the natural logarithm of the ratio of an industry's sales in year $t$ to its sales in year $t$-3. Employment shock (Emp_Shock) is defined in a similar way. Market_Volatility is the annualized standard deviation of the CRSP value-weighted index in a given year and controls for the anticipated differences in stock market volatility between periods of merger waves and out-of-wave periods. Shleifer and Vishny (2003) have shown that merger activity is influenced by the relative overvaluation of an acquiring firm's stock, which is likely to vary with stock market conditions. Therefore, we add a dummy variable, Market_Upswing, that has the value of one if the annualized market return is higher than the risk-free rate (following Ang et al., 2006), and zero otherwise. Market returns are again based on the CRSP value-weighted index.

To control for recent M\&A experience we use a dummy variable, Prior_M\&A_Activity, that takes the value of one if the firm has been engaged in M\&A 
activity either as bidder or target in the previous year, and zero otherwise. We capture the expected poor performance of late-wave deals from herding behavior (Goel and Thakor, 2010) with the dummy variable, Herding, that is equal to one if a deal has been initiated during the second half of a wave, and zero otherwise. To proxy for information asymmetry and ease of monitoring in the target firm, we use the geographic Distance between the acquirer and target headquarters at the time of the acquisition announcement (Uysal et al., 2008). Zip codes of the acquirer and the target are obtained from SDC Platinum. Latitude and longitude coordinates are collected from the U.S. Census Bureau's Gazetteer Place and Zip Code Database. ${ }^{8}$

Table 1 shows that $56 \%$ of acquirers in the combined sample are engaged in M\&A activity in the previous year compared to only $27 \%$ of the firms included in the ExecuComp sample, suggesting that a sub-sample of firms are serial acquirers. $21.6 \%$ of the transactions in the combined sample are acquisitions of public firms ${ }^{9}$ while $44.6 \%$ are acquisitions of privately held firms. The remaining deals are takeovers of subsidiary firms. $40.7 \%$ of the deals are cross-industry transactions, which is comparable to the proportion of diversifying deals reported by Morck et al. (1990) and Cornett et al. (2003). The vast majority of the deals have only one bidder, in line with the findings of previous research (Alexandridis et al., 2010). ${ }^{10}$ The average acquirer completes the deal in 2.24 months $(0.187$ years $)$ while approximately $25 \%$ of the deals are completed on the announcement date.

\footnotetext{
${ }^{8}$ Following Uysal et al. (2008) we expect that geographical distance is correlated with greater synergies and asymmetrically informed bidders, both of which leads to higher gains for acquiring firms. Bick et al. (2017) find that deal premiums and time to completion are increasing as the distance between the acquirer and the target increases due to higher information asymmetry. Chhaochharia et al. (2012) find that closer geographical distance between institutional investors and firm management allows for greater monitoring, improves internal corporate governance, and is associated with fewer empire building activities.

${ }^{9}$ Croci and Petmezas (2015) report a similar percentage of public deals $(21.55 \%)$ in their sample.

${ }^{10}$ Alexandridis et al. (2010) show that $3.03 \%$ of the deals in their US sample have at least one competing offer as reported in SDC. This percentage is $1.03 \%$ in our sample but Alexandridis et al. examine only acquisitions of public targets which are subject to greater publicity and, therefore, an increased likelihood of competitive bidding. If we refine our sample to public deals only, the percentage of deals with more than one bidders rises to $3.89 \%$.
} 


\section{Empirical findings}

\subsection{Executive compensation and the propensity to acquire}

Table 2 presents mean/median differences in CEO compensation for the combined sample. Panel A presents dollar values for Delta, Vega, and cash compensation. Panel B presents differences in these variables standardized by CEO total compensation to control for firm size. In total, 3,312 transactions ( $31 \%$ of the sample) take place during merger waves, which is comparable to Duchin and Schmidt (2013).

The difference in mean CEO Delta and Vega in- and out-of-wave acquisitions is significantly positive (\$2.393million vs \$1.618million) and negative (\$149,910 vs $\$ 172,740)$, respectively. These results are repeated in Panel B when we scale by total compensation. Cash compensation exhibits a similar pattern with in-wave acquiring CEOs receiving 2.9\% more of their total compensation through salary and cash bonus payments than out-of-wave acquiring CEOs.

These findings provide preliminary evidence that managers who make out-of-wave acquisitions have stronger pay-risk incentives than those who acquire during waves. We interpret this as evidence of sub-optimal contracting during merger waves, which in turn could reduce the subsequent performance of merger decisions (Bouwman et al., 2009; Goel and Thakor, 2010).

We extend the univariate results of Table 2 by examining whether the propensity to acquire is affected by CEO incentives, and whether this varies conditional on merger waves. We conduct this testing using the ExecuComp sample of 44,673 firm-year observations, and expect a positive relation between $V e g a$ and the propensity to acquire (Agrawal and Mandelker, 1987; Croci and Petmezas, 2015).

Following Harford (1999), we construct a probit model that predicts acquiring firms based on a number of explanatory variables at the year-end prior to the acquisition 
announcement. The dependent variable, Acquisition, equals one if a firm makes an acquisition announcement in a given year, and zero otherwise. In addition to our compensation variables, the propensity to acquire is also related to firm characteristics including acquirer's size, past performance, cash, growth prospects, leverage, non-cash working capital, overvaluation, industry sales and employment shocks, market volatility, stock market performance, and prior M\&A activity. Z-statistics are based on robust standard errors clustered at the firm level.

Table 3 presents the results. In Model 1 we find a positive relation between both Delta and Vega and the propensity to acquire, but the effect is significant only for Vega. On the other hand, the relation between the likelihood to acquire and cash compensation is negative and statistically significant, suggesting that greater cash compensation reduces risk-seeking incentives (Datta et al., 2001; Brick et al., 2006). By construction, the In-Wave_Year dummy is positively related to the likelihood of acquisitions.

The remaining control variable coefficients are as expected. Large firms with high sales growth and non-cash working capital are more likely to acquire (Harford, 1999) and so are firms with good past performance (Croci and Petmezas, 2015). Firms with recent M\&A activity are more likely to undertake acquisitions and highly leveraged firms tend to avoid the increased risk associated with acquisitions (Uysal, 2011). The propensity to acquire is also negatively related to the bidder's book-to-market ratio.

Partitioning the sample between in-wave and out-of-wave years in Models 2 and 3 respectively confirms our base prediction. Both Delta and Vega are unrelated to the propensity to acquire during waves (Model 2), whereas Vega is positive and statistically significant at the 1 percent level outside of waves (Model 3). The results show that incentive compensation induces acquisition activity only outside of merger waves, and provides support for $H_{1}$. 
The sign and significance of the remaining control variables are consistent with the hypothesis of distorted managerial incentives during merger waves. For instance, the positive and statistically significant coefficient of Market_Volatility in Model 2 indicates that managers' decisions to acquire are characterized by abnormal stock market volatility, while leverage is negatively related to acquisition activity for out-of-wave firm years only, suggesting that leverage does not constrain acquisition investments during waves. ${ }^{11}$

The results in Table 3 suggest that ex-ante CEO compensation incentives fail to motivate managers to undertake mergers during wave periods. To explain why this may be the case, we mimic Harford and $\mathrm{Li}$ (2007) and Fu et al. (2013) to examine changes in CEO compensation surrounding mergers, and whether they vary across in-wave and out-of-wave periods. Fich et al. (2014) find that mergers are associated with large increases in CEO compensation and Harford and Li (2007) report that this arises specifically due to new executive stock and option awards. Fu et al. (2013) show that managers of overvalued firms benefit from higher ex-post increases in compensation in comparison to managers of overvalued firms that do not undertake mergers.

In Table 4 we examine changes in Cash compensation, New Grants, and Total Compensation from one year prior to the merger announcement to one year following merger completion, conditional on merger waves. CEOs in both groups experience large increases in mean and median Total Compensation following mergers, but the mean increase of $\$ 1,739,720$ for in-wave acquiring CEOs is statistically higher than the increase of $\$ 810,300$ for out-of-wave acquiring CEOs. Breaking compensation down between cash and equitybased pay, in-wave acquiring CEOs received significantly larger new grants of options and

\footnotetext{
${ }^{11} \mathrm{We}$ also estimate our models in Table 3 using Tobit regressions. Our core finding of a positive relation between Vega and the propensity to acquire outside of merger waves holds (significant at the 1 percent level). In these models we replace the Acquisition dummy variable with Acquisition_Spending, which is the sum of all deal values for completed mergers during the firm's financial year scaled by revenue at the previous financial year-end.
} 
stock following completion of the merger relative to out-of-wave CEOs. The results are clearly skewed and the difference in mean $(\$ 1,095,870)$ are notably larger than median $(\$ 33,600)$ awards, but both differences are statistically significant and highlight that in-wave acquiring CEOs are awarded new equity-based compensation grants following completion of the merger. ${ }^{12}$

The results in Table 4 provide some validation for the observed weak relationship between ex-ante compensation incentives and merger propensity during in-wave periods in Table 3. Acquiring CEOs during merger waves receive larger increases in compensation following completion of the merger and this dominates the incentives from ex-ante compensation to undertake risky investment decisions.

\subsection{Deal performance across in-wave and out-of-wave periods}

Prior to examining the relation between incentive compensation and firm performance, we compare firm performance between in- and out-of-wave acquisitions in Table 5. Panel A presents differences in deal announcement returns between in-wave and out-of-wave acquirers. $\operatorname{CARs}(0,1)$ is the bidder's cumulative abnormal returns over a two-day window $(0$, +1 ) where day 0 is the acquisition announcement date and CARs are estimated using the market model. The estimation period is from 200 days to 60 days before the acquisition announcement and market returns are based on the CRSP value-weighted index. The results highlight a small positive market reaction to merger announcements for acquiring firms

\footnotetext{
${ }^{12}$ Cheng and Indjejikian (2009) find that the enactment of state-level antitakeover laws leads to an increases in levels of CEO compensation and the sensitivity of changes in compensation to financial performance. One interpretation of their findings is that a reduction in merger activity, and therefore a reduction in the possibility of waves occurring, leads to an increase in pay and this contradicts our own findings. However, the research design in Cheng and Indjejikian focuses on compensation as an outcome of an agency problem where managers insulated from the threat of takeover receive larger increases in pay, which the study links to rewards for luck. In this sense, the results are plausibly consistent with the general findings of Harford and Li (2007) and Fich et al. (2014) amongst others that compensation increases surrounding mergers can be driven by managerial selfinterest and reflect underlying agency conflicts between managers and shareholders.
} 
(significant at the 1 percent level). Panels $\mathrm{B}$ and $\mathrm{C}$ test whether long-term post-acquisition stock price performance differs between in- and out-of-wave acquiring firms. $2 y A B H R$ is the bidder's 2-year buy-and-hold daily return following the acquisition effective date minus the 2-year buy-and-hold daily return of the matched firm for the same period. Firms are matched by Fama-French industry, year, size (market capitalization) and book-to-market ratio. To address concerns regarding selection bias in the decision to acquire, we also calculate 2yABHR_PSM using a propensity-score matched firm for the non-acquiring benchmark. Propensity scores are estimated following Harford (1999) to predict bidders. The model is estimated separately for each year and every acquirer is matched to the firm within the ExecuComp database with the closest propensity score in the same industry-year. For both measures above, we require that the matched firm has not been involved in any M\&A activity for a period of three years surrounding the acquisition effective date. Matched firms delisted before the completion of the 2-year post-acquisition period are replaced with the next closest match on the delisting date.

Deals initiated during merger waves underperform relative to out-of-wave deals. For example, the mean (median) $2 y A B H R$ is $5.46 \%$ (4.23\%) for out-of-wave deals while long-run returns are insignificantly different to zero for in-wave acquirers. The differences are significant at the 1 percent level for both measures of long-run stock price returns.

Finally, Panels D and E show that in-wave M\&A transactions are followed by significantly weaker operating performance relative to out-of-wave deals, and the difference in both means and medians is again significant at the 1 percent level. $D_{-} R O A$ is the difference between the acquirer's return on assets (ROA) in the second year following the effective date $(\mathrm{t}+2)$ and the acquirer's ROA at the acquisition year $(\mathrm{t})$. ROA is defined as operating income before depreciation divided by book value of total assets. $D_{-} R O A \_P S M$ is the change in bidder's return on assets (ROA) over a 2-year period following the acquisition 
effective date minus the change in ROA of the propensity-score matched firm for the same period.

Overall, the findings are consistent with previous studies that document stock price and operating long-run underperformance for acquisitions initiated during merger waves (Bouwman et al., 2009; Goel and Thakor, 2010; Fu et al., 2013). Differences in short-run announcement returns across the two groups are economically small.

\subsection{CEO compensation, merger waves and acquisition performance}

Table 6 presents regressions of the relation between CEO compensation and short-term announcement returns for the combined sample. For this sample, Delta and Vega are positively associated with short-term announcement returns and the control variables act as expected. These results are consistent with previous research on executive compensation incentives and short-run acquisition performance (see, for example, Datta et al., 2001; Grinstein and Hribar, 2004; Minnick et al., 2011).

Models 2 and 3 partition acquisitions into those initiated inside and outside of merger waves, respectively. Vega is positively related to announcement returns only outside of waves while Delta is positively related to announcement returns inside and outside of waves. We interpret our findings as showing that the positive impact of incentive pay on risky acquisition decisions is effective only outside of merger waves.

Turning to long-run post-acquisition performance, Table 7 examines whether the difference in long-run stock-price performance can be attributed to differences in CEO compensation. Models 1 and 4 present the results for all M\&A transactions. Delta is positively related to long-run acquirer stock price performance in both models, while Vega is significantly related to performance in Model 1 only. Cash compensation is unrelated to longrun post acquisition performance. The significantly negative coefficient of the In_Wave 
dummy (at the 10\% level and 5\% level in Models 1 and 4 respectively) confirms our univariate results that in-wave deals underperform out-of-wave deals in the long-run.

Models 2 and 5 present results for acquisitions made during waves and Models 3 and 6 present results for out-of-wave transactions. Model 2 shows that Vega is unrelated to longrun stock-price performance when acquisitions are initiated during merger waves compared to Model 3 where Vega is statistically significant (at the 1 percent level) and positively related to acquirer's long-run financial performance. Delta is positively associated with longrun financial performance in both in-wave and out-of-wave sub-samples. However, using a seemingly unrelated estimation to compare the Delta coefficient between in-wave (model 5) and out-of-wave deals (model 6), we find that Delta has a significantly higher impact on long-run stock-price performance outside merger waves.

The final test in this section examines the relation between executive compensation and long-run operating performance. Across all models we find that Delta is unrelated to acquisition performance with Vega positive and significant in Model 6 (at the $10 \%$ level). Delta being unrelated to post-acquisition operating performance perhaps reflects the weaker link between stock-based compensation and accounting performance. Cash compensation is also unrelated to deal performance, which is consistent with our earlier results. The negative and statistically significant (at the 1 percent level) coefficient of the In_Wave dummy in Model 1 supports our univariate findings that in-wave deals significantly underperform outof-wave deals in the long-run.

Following Duchin and Schmidt (2013) we propose that increased information asymmetry and weak monitoring of acquiring firm managers during merger waves reduces the penalties for making bad acquisitions and contributes to the inferior performance of in- 
wave merger deals. ${ }^{13}$ If acquiring firm CEOs can benefit from increases in ex-post compensation following even poorly performing mergers, the ex-ante benefits of their compensation structure will become unimportant. Collectively, the findings from Tables 6 to 8 provide support for $\mathrm{H}_{2}$.

\subsection{Merger waves and post-acquisition return dispersion}

Our results show that in-wave bidders experience lower post-acquisition returns relative to out-of-wave bidders and this difference can partially be attributed to weaker CEO compensation incentives. In this section, we test hypothesis, $H_{3}$, and ask whether the dispersion of post-acquisition abnormal returns varies between high and low incentive compensation managers and across in- and out-of-wave acquiring firms. If the decision to acquire during a merger wave is associated with higher information asymmetries, we expect greater cross-sectional dispersion of post-acquisition returns for in-wave acquirers relative to out-of-wave acquiring firms. The testing presented here provides a measure of the relation between incentive compensation and consistency in the performance of merger decisions.

We calculate the cross-sectional standard deviation of acquirer daily cumulative abnormal returns and propensity-score matched abnormal buy-and-hold returns for four different time intervals: $3,6,9$, and 12 months after completion of the acquisition. In benchmarking against non-acquiring firms with the $A B H R \_P S M$ variable we also control for the possibility that the dispersion of returns is higher in general during in-wave periods when information asymmetries are higher.

Table 9 presents the results. We confirm that the cross-sectional dispersion of postacquisition returns is significantly higher for in-wave deals relative to out-of-wave deals for all measures of abnormal stock price returns and post-acquisition time periods. All

\footnotetext{
${ }^{13}$ In separate tests (untabulated but available upon request from the authors) we confirm that acquirer's idiosyncratic risk, used as proxy for monitoring costs by a number of studies (see, for instance, Demsetz and Lehn, 1985; Himmelberg et al., 1999; Core and Guay, 1999) is significantly higher during merger waves.
}

This article is protected by copyright. All rights reserved. 
differences are significant at the 1 percent level based on an F-test comparison of sample variances.

We extend this analysis to examine how incentive compensation affects the dispersion of abnormal returns. The results are presented in Table 10. The sample of acquisitions is partitioned into High and Low incentive sub-samples based on the level of acquiring CEO incentive compensation. Bidding firms with Delta above (equal or below) the sample median are classified as High (Low) Delta. We perform a similar split to identify High Vega and Low Vega acquiring firms. ${ }^{14}$

Panel A presents differences in the standard deviation of cross-sectional postacquisition returns for CEOs with high and low compensation incentives. High Vega acquiring firms experience significantly lower cross-sectional dispersion of returns than Low Vega acquirers over each time period and measure of abnormal returns. All differences are significant at the 1 percent level. Our findings for Delta are somewhat weaker, especially for the cross-sectional standard deviation of CARs. These findings are in line with expectations since Vega is a measure of CEO's risk-seeking compensation incentives and can therefore explain changes in risk-seeking incentives better than Delta (Coles et al., 2006).

In Panels $\mathrm{B}$ and $\mathrm{C}$ we present the cross-sectional dispersion of returns for in-wave and out-of-wave acquirers respectively. We find in Panel B that compensation incentives provided to in-wave acquiring managers cannot, in the majority of cases, explain differences in the dispersion of post-acquisition returns for this group of firms. On the other hand, our results in Panel $\mathrm{C}$ show that the higher Vega for out-of-wave acquiring CEOs can explain part of the cross-sectional dispersion in post-acquisition abnormal returns, with higher Vega associated with a lower cross-sectional dispersion of post-acquisition abnormal returns. The

\footnotetext{
${ }^{14}$ The results remain robust if the median of the extended ExecuComp sample is used instead of the median of the combined sample.
} 
results are stronger for Vega than for Delta, which is in line with our findings in the previous section and reflects the focus of this test on post-acquisition dispersion of stock price returns. Collectively, the results in this section provide strong support for $H_{3}{ }^{15}$ We attribute the lower dispersion of post-acquisition returns for High Vega CEOs as evidence of greater consistency in the quality of merger decisions, and the positive effect of ex-ante compensation incentives on quality of decision making is not present during in-wave periods.

\subsection{Further analysis}

This section summarizes the results of further analysis and additional robustness testing to the main results reported in the paper. ${ }^{16}$

\subsubsection{Endogeneity in compensation design and propensity to acquire}

A concern with the findings in Table 3 is potential endogeneity between the propensity to acquire and the likelihood of a merger wave. We assume that waves induce managers to undertake mergers at the firm-level, but waves themselves are a result of an abnormal number of merger decisions by individual firms. To examine this issue we follow Ahern and Harford (2014) and estimate a Granger causality test. We find that both firm-level mergers and merger waves Granger-cause one another, which provides validity for our regression design where merger waves are allowed to cause firm-level merger decisions. The results are also consistent with the herding behaviour displayed in Goel and Thakor (2010), who find that envy drives CEOs to undertake mergers in the latter stages of merger waves.

To further address concerns surrounding endogeneity of compensation design with specific reference to takeover market conditions, we follow Coles et al. (2006) and Cohen et

\footnotetext{
${ }^{15}$ Our results in Tables 9 and 10 are unchanged if we calculate ABHRs using control firms based on industry, size and book-to-market following the method outlined for post-acquisition performance.

${ }^{16}$ For brevity we do not report these results but they are available on request from the authors.
} 
al. (2013) and estimate a system of 3SLS regressions for Acquisition, Delta and Vega where we allow for takeover market conditions, wave characteristics, and corporate investment expenditures to affect incentive design. The results confirm our main finding that Vega is positively related to merger propensity and the effect is driven by the sub-sample of out-ofwave years.

\subsubsection{Predicted Delta and Vega}

Given that external market conditions can differ significantly between in-wave and out-ofwave periods, CEO incentive compensation can be more volatile during merger waves due to the presence of industry shocks, rising stock markets, increased monitoring costs, corporate valuations and stock market volatility. We therefore perform a further test to examine whether these factors drive the design of CEO compensation contracts away from optimal contracting during periods of intense merger activity. We estimate optimal levels of Delta and Vega following Core and Guay (1999) and extend their model with an additional set of

control variables to account for the impact of the market conditions described above. We find the standard deviation of the residuals obtained from the model, which shows the extent to which CEO equity incentives deviate from their optimal (predicted) levels, is significantly higher during merger waves. The greater dispersion in residuals from compensation regressions support for our main findings of reduced efficiency of (sub-optimally set) CEO incentives during wave periods.

We also re-run all our multivariate tests by splitting our CEO Delta and Vega measures into their predicted (optimal) and residual components to address endogeneity concerns that takeover market conditions can simultaneously affect both the design of CEO compensation contracts and acquisition decisions. The results confirm our earlier findings 
showing that the endogenously determined Vega induces acquisition activity only when it is optimal to do so, i.e. outside merger wave periods. Using our predicted and residual values of Delta and Vega, we can also confirm the findings from Tables 6-8. In addition, the endogenously determined (predicted) Delta and Vega provide further support to the findings of Table 10 with regard to the higher dispersion of post-acquisition cross-sectional returns during merger waves.

\subsubsection{Acquiring firm corporate governance}

Cyert et al. (2002) examine the conflict of interest between boards and CEOs in setting compensation under the threat of a takeover and propose that boards and equity ownership by large outside shareholders are substitutes in mitigating the agency conflict. To examine whether this influences our own results, we add a control variable, CEO/Chairman, which takes the value of one if the CEO/chairman role is combined, and zero otherwise. The CEO/Chairman dummy is insignificant in most regressions and does not affect our main findings.

In further testing we add the co-opted director variables examined in Coles et al. (2014). Data availability for these measures covers approximately $50 \%$ of our sample. Adding these variables weakens the statistical significance of Vega in our regressions. However, we find the same weak significance if we re-estimate our findings for the subsample of firms where the data used in Coles et al. (2014) overlaps with our own sample, suggesting that it is the loss of data that weakens our findings rather than the inclusion of new controls for acquiring firm corporate governance. 


\subsubsection{Cross-industry merger waves}

Ahern and Harford (2014) show that cross-industry merger waves are driven by different factors from those that drive intra-industry waves. Given this, we re-run our wave simulations to identify merger waves taking only cross-industry deals into account. All results are then reestimated based on the new cross-industry only wave specification. Because our definition of merger waves is data-driven, excluding intra-industry deals changes the merger wave dates and consequently some aspects of our results.

Constraining the analysis to cross-industry merger waves only, the in-wave dummy is no longer significantly related to the propensity for individual firms to undertake mergers. Moreover, we no longer find a significant difference in performance (either short- or longrun) between in-wave and out-of-wave deals. These findings suggest that our results for the relation between $\mathrm{CEO}$ compensation incentives and mergers are not driven by cross-industry merger waves.

\subsubsection{Frequent acquirers}

Aktas et al. (2013) find that gains to merger transactions improve with acquisition frequency and attribute this to learning through prior experience. Similarly, Golubov et al. (2015) present evidence that some firms are better acquirers than others, even after controlling for firm- and deal-specific characteristics. To examine if frequent acquirers drive our results, we re-run our main analysis separately for frequent and infrequent acquirers. Following Fuller et al. (2002) and Golubov et al. (2015), we define Frequent as a dummy variable that is equal to one if the acquirer has completed at least five deals over any three-year window surrounding the deal, and zero otherwise from SDC Platinum.

For propensity to engage in Acquisitions, our results for Vega in Table 3 are driven by infrequent acquirers. Moreover, the role of Vega in reducing the dispersion of cross-sectional 
post-acquisition stock price returns for out-of-wave acquirers in Table 10 is strongest for infrequent acquirers. Frequent acquirers are likely to be distinct from infrequent acquirers in their investment opportunities (Golubov et al., 2015) and our findings suggest that compensation incentives are not required to motivate managers to undertake risky acquisition investments at these firms in the same way observed for infrequent acquirers.

\section{Conclusions}

We provide new evidence that in-wave merger decisions and performance can be explained, in part, by differences in the compensation incentives of acquiring firm CEOs. CEOs who initiate acquisitions outside of merger waves have compensation contracts more closely aligned with the predictions of optimal contracting. The wealth of out-of-wave acquiring managers is more sensitive to the volatility of stock price returns and CEOs who acquire inwave receive a higher proportion of cash compensation. Pay-risk sensitivity, Vega, is positively associated with the propensity to acquire, but only outside of merger waves. We find that private benefits of control, expected ex-post increases in cash compensation, and higher monitoring costs during in-wave periods dominate the expected positive relation between incentive compensation and propensity to acquire during waves. Stronger monitoring and compensation incentives for out-of-wave acquiring CEOs can overcome such concerns, but this is not the case for in-wave acquiring CEOs.

Differences in the structure of executive compensation have direct implications for acquiring firm performance. Pay-performance, Delta, and pay-risk, Vega, sensitivity are positively associated with short-term and long-term acquiring firm stock price performance when an acquisition is initiated outside of a merger wave. We find no consistent relation between ex-ante compensation incentives and acquiring firm performance during merger waves. We attribute this to the weaker incentives provided to in-wave acquiring CEOs and 
the reduced likelihood of being blamed for poorly performing acquisitions. As a result, inwave deals also experience greater dispersion in cross-sectional post acquisition returns.

This research adds to the debate on the underperformance of mergers initiated during waves. We extend the analysis of Duchin and Schmidt (2013) who find that adverse selection costs and weak monitoring of acquiring firm managers during merger waves can explain the poor performance of these transactions. Our findings show that part of the explanation for poor post-acquisition performance lies in the weak compensation incentives provided to acquiring firm CEOs during waves. We also highlight that compensation committees should consider external market conditions when setting appropriate ex-ante incentives for senior corporate executives.

\section{References:}

Agrawal, A., Mandelker, G., 1987. Managerial incentives and corporate investment and financing decisions. Journal of Finance 42, 823-838.

Ahern, K.R., Harford, J., 2014. The importance of industry links in merger waves. Journal of Finance 69, 527-576.

Aktas, N., de Bodt, E., Roll, R., 2013. Learning from repetitive acquisitions: Evidence from the time between deals. Journal of Financial Economics 108, 99-117.

Alexandridis, G., Petmezas, D., Travlos, N.G., 2010. Gains from mergers and acquisition around the world: New evidence. Financial Management 39, 1671-1695.

Andrade, G., Mitchell, M., Stafford, E., 2001. New evidence and perspectives on mergers. Journal of Economic Perspectives 15, 103-120.

Ang, A., Chen, J., Xing, Y., 2006. Downside risk. Review of Financial Studies 19, 11911239.

Asquith, P., Bruner, R.F., Mullins, D.W.Jr., 1983. The gains to bidding firms from merger. Journal of Financial Economics 11, 121-139.

Bi, X.G., Gregory, A., 2011. Stock market driven acquisitions versus the Q theory of takeovers: The UK evidence. Journal of Business Finance and Accounting 38, 628-656.

Bick, P., Crook, M.D., Lynch, A.A., Walkup, B.R., 2017. Does distance matter in mergers and acquisitions? Journal of Financial Research 40, 33-54.

Billett, M.T., Mauer, D.C., Zhang, Y., 2010. Stockholder and bondholder wealth effects of CEO incentive grants. Financial Management 39, 463-487.

Bouwman, C.H.S., Fuller, K., Nain, A.S., 2009. Market valuation and acquisition quality: Empirical evidence. Review of Financial Studies 22, 487-517.

Brick, I.E., Palmon, O., Wald, J.K., 2006. CEO compensation, director compensation, and firm performance: Evidence of cronyism? Journal of Corporate Finance 12, 403-423.

Cheng, S., Indjejikian, R.J., 2009. The market for corporate control and CEO compensation: Complements or substitutes? Contemporary Accounting Research 26, 701-728.

Chhaochharia, V., A. Kumar, Niessen-Ruenzi, A., 2012. Local investors and corporate governance. Journal of Accounting and Economics 54, $42-67$. 
Cohen, D.A., Dey, A., Lys, T.Z., 2013. Corporate governance reform and executive incentives: Implications for investments and risk-taking. Contemporary Accounting Research, 30, 1296-1332.

Coles, J. L., Daniel, N.D., Naveen, L., 2006. Managerial incentives and risk-taking. Journal of Financial Economics 79, 431-468.

Coles, J.L., Daniel, N.D., Naveen, L., 2014. Co-opted boards. Review of Financial Studies 27, 1751-1796.

Core, J., Guay, W., 1999. The use of equity grants to manage optimal equity incentive levels. Journal of Accounting and Economics 28, 151-184.

Core, J., Guay, W., 2002. Estimating the value of employee stock option portfolios and their sensitivities to price and volatility. Journal of Accounting Research 40, 613-630.

Cornett, M.M., Hovakimian, G., Palia, D., Tehranian, H., 2003. The impact of managershareholder conflict on acquiring bank returns. Journal of Banking and Finance 27, 103131.

Croci, E., Petmezas, N., 2015. Do risk-taking incentives induce CEOs to invest? Evidence from acquisitions. Journal of Corporate Finance 32, 1-23.

Cyert, R.M., Kang, S.H., Kumar, P., 2002. Corporate governance, takeovers, and topmanagement compensation: Theory and evidence. Management Science 48, 453-469.

Datta, S., Iskander-Datta, M., Raman, K., 2001. Executive compensation and corporate acquisition decisions. Journal of Finance 56, 2299-2336.

Demsetz, H., Lehn, K., 1985. The structure of corporate ownership: causes and consequences. Journal of Political Economy, 1155-1177.

Duchin, R., Schmidt, B., 2013. Riding the merger wave: Uncertainty, reduced monitoring, and bad acquisitions. Journal of Financial Economics 107, 69-88.

Edmans, A., Gabaix, X., 2011. The effect of risk on the CEO market. Review of Financial Studies 24, 2822-2863.

Fama, E.F., French, K.R., 1997. Industry costs of equity. Journal of Financial Economics 43, 153-193.

Faccio, M., Masulis, R.W., 2005. The Choice of payment method in European mergers and acquisitions. Journal of Finance 60, 1345-1388.

Fich, E.M, Starks, L.T., Yore, A.S., 2014. CEO deal-making activities and compensation. Journal of Financial Economics 114, 471-492.

Fu, F., Lin, L., Officer, M.S., 2013. Acquisitions driven by stock overvaluation: Are they good deals? Journal of Financial Economics 109, 24-39.

Fuller, K., Netter, J., Stegemoller, M., 2002. What do returns on acquiring firms tell us? Evidence from firms that make many acquisitions. Journal of Finance 57, 1763-1793.

Garfinkel, J.A., Hankins, K.W., 2011. The role of risk management in mergers and merger waves. Journal of Financial Economics 101, 515-532.

Goel, A.M., Thakor, A.V., 2010. Do envious CEOs cause merger waves? Review of Financial Studies 23, 487-517.

Golubov, A., Petmezas, D., Travlos, N.G., 2012. When it pays to pay your investment banker: new evidence on the role of financial advisors in M\&As. Journal of Finance 67, 271-311.

Golubov, A., Yawson, A., Zhang, H., 2015. Extraordinary acquirers. Journal of Financial Economics 116, 314-330.

Gorton, G., Kahl, M., Rosen R.J., 2009. Eat or be eaten: a theory of mergers and firm size. Journal of Finance 64, 1291-1344. 
Grinstein, Y., Hribar, P., 2004. CEO compensation and incentives: Evidence from M\&A bonuses. Journal of Financial Economics 73, 119-143.

Hansen, R.G., Lott, J.R.Jr., 1996. Externalities and corporate objectives in a world with diversified shareholder/consumers. Journal of Financial and Quantitative Analysis 31, 4368.

Harford, J., 1999. Corporate cash reserves and acquisitions. Journal of Finance 62, 19691997.

Harford, J., 2005. What drives merger waves? Journal of Financial Economics 77, 529-560.

Harford, J., Li, K., 2007. Decoupling CEO wealth and firm performance: The case of acquiring CEOs. Journal of Finance 62, 917-949.

Himmelberg, C., Hubbard, G., Palia, D., 1999. Understanding the determinants of managerial ownership and the link between ownership and performance. Journal of Financial Economics 53, 353-384.

Jensen, M., 1988. Takeovers: Their causes and consequences. Journal of Economic Perspectives 2, 21-48.

Lahlou, I., Navatte, P., 2017. Director compensation incentives and acquisition performance. International Review of Financial Analysis. 53, 1-11.

Mavis, C.P., McNamee, N., Petmezas, D., Travlos, N.G., 2017. Selling to buy: asset sales and M\&As. Working Paper, University of Surrey.

Minnick, K., Unal, H., Yang, L., 2011. Pay for performance? CEO compensation and acquirer returns in BHCs. Review of Financial Studies 24, 439-472.

Mitchell, M.L., Mulherin, J.H., 1996. The impact of industry shocks on takeover and restructuring activity. Journal of Financial Economics 41, 193-229.

Moeller, S.B., Schlingemann, F.P., Stulz, R.M., 2004. Firm size and the gains from acquisitions. Journal of Financial Economics 73, 201-228.

Moeller, S.B, Schlingemann, F.P., Stulz, R.M., 2005. Wealth destruction on a massive scale? A study of acquiring firm returns in the recent merger wave. Journal of Finance 60, 757782 .

Morck, R., Shleifer, A., Vishny, R.W., 1990. Do managerial objectives drive bad acquisitions? Journal of Finance 45, 31-48.

Officer, M.S., 2007. The price of corporate liquidity: Acquisition discount for unlisted targets. Journal of Financial Economics 83, 571-598.

Ovtchinnikov, A.V., 2013. Merger waves following industry deregulation. Journal of Corporate Finance 21, 51-76.

Powell, R., Stark, A.W., 2005. Does operating performance increase post-takeover for UK takeovers? A comparison of performance measures and benchmarks. Journal of Corporate Finance 11, 293-317.

Powell, R., Yawson, A., 2005. Industry aspects of takeovers and divestitures: Evidence from the UK. Journal of Banking and Finance 29, 3015-3040.

Powell, R., Yawson, A., 2007. Are corporate restructuring events driven by common factors? Implications for takeover prediction. Journal of Business Finance and Accounting 34, 1169-1192.

Rau, P.R., Vermaelen, T., 1998. Glamour, value and the post-acquisition performance of acquiring firms. Journal of Financial Economics 49, 223-253.

Rhodes-Kropf, M., Robinson, D.T., Viswanathan, S., 2005. Valuation waves and merger activity: The empirical evidence. Journal of Financial Economics 77, 561-603.

Rhodes-Kropf, M., Viswanathan, S., 2004. Market valuation and merger waves. Journal of Finance 59, 2685-2718. 
Roll, R., 1986. The hubris hypothesis of corporate takeovers. Journal of Business 59, 197216.

Ross, S.A., 2004. Compensation, incentives, and the duality of risk aversion and riskiness. Journal of Finance 59, 207-225.

Shleifer, A., Vishny, R.W., 2003. Stock market driven acquisitions. Journal of Financial Economics 70, 295-311.

Travlos, N.G., 1987. Corporate takeover bids, methods of payment, and bidding firms' stock returns. Journal of Finance 42, 943-963.

Uysal, V.B., Kedia, S., Panchapagesan, V., 2008. Geography and acquirer returns. Journal of Financial Intermediation 17, 256-275.

Uysal, V.B., 2011. Deviation from the target capital structure and acquisition choices. Journal of Financial Economics 102, 602-620.

Yung, C., Colak, G., Wang, W., 2008. Cycles in the IPO market. Journal of Financial Economics 89, 192-208.

\section{Table 1: Summary statistics}

Panel A presents summary statistics for the extended ExecuComp sample of 44,673 firm-year observations over the period 1992-2015. Panel B presents summary statistics for the sample of 10,684 completed U.S. acquisitions from SDC Platinum over the period January 1, 1993, to December 31, 2016. Data on executive compensation are from ExecuComp, stock price data from CRSP and accounting data from Compustat. Definitions of all variables are described in Appendix A.

\begin{tabular}{|c|c|c|c|c|c|c|}
\hline Variable & Mean & $\begin{array}{c}\text { Standard } \\
\text { Deviation }\end{array}$ & $\begin{array}{c}25 \text { th } \\
\text { Percentile }\end{array}$ & Median & $\begin{array}{c}75 \text { th } \\
\text { Percentile }\end{array}$ & $\begin{array}{c}\text { Number of } \\
\text { Observations }\end{array}$ \\
\hline \multicolumn{7}{|l|}{ Panel A: ExecuComp sample } \\
\hline \multicolumn{7}{|l|}{ Compensation Variables } \\
\hline Delta $(\$ 000 \mathrm{~s})$ & 886 & 8,538 & 45 & 154 & 464 & 42,205 \\
\hline Vega (\$000s) & 109 & 259 & 6 & 32 & 105 & 42,205 \\
\hline Cash_Comp (\$000s) & 1,355 & 1,926 & 620 & 926 & 1,464 & 44,673 \\
\hline New_Grants (\$000s) & 3,055 & 9,777 & 99 & 1,104 & 3,307 & 44,673 \\
\hline Total_Comp (\$000s) & 5,251 & 10,749 & 1,353 & 2,833 & 5,994 & 44,673 \\
\hline \multicolumn{7}{|l|}{ Firm Characteristics } \\
\hline Size & 3.311 & 0.774 & 2.750 & 3.250 & 3.810 & 40,866 \\
\hline Past_ABHR & 0.080 & 0.638 & -0.206 & 0.001 & 0.234 & 40,098 \\
\hline Cash/Assets & 0.142 & 0.170 & 0.022 & 0.072 & 0.201 & 40,865 \\
\hline $\mathrm{B} / \mathrm{M}$ & 0.566 & 0.870 & 0.270 & 0.450 & 0.690 & 40,223 \\
\hline $\mathrm{ROA}$ & 0.122 & 0.124 & 0.067 & 0.122 & 0.178 & 40,786 \\
\hline Sales_Growth & 0.031 & 0.113 & -0.011 & 0.023 & 0.066 & 39,862 \\
\hline Leverage & 0.225 & 0.201 & 0.057 & 0.201 & 0.341 & 40,866 \\
\hline $\mathrm{P} / \mathrm{E}$ & 20.124 & 159.627 & 10.515 & 17.135 & 26.196 & 40,551 \\
\hline NC_Working_Cap & 0.101 & 0.177 & -0.017 & 0.078 & 0.203 & 35,391 \\
\hline Overvaluation & 0.550 & 0.497 & 0.000 & 1.000 & 1.000 & 44,585 \\
\hline Sales_Shock & 0.004 & 0.260 & -0.109 & 0.015 & 0.144 & 44,585 \\
\hline Emp_Shock & 0.016 & 0.242 & -0.082 & 0.031 & 0.136 & 44,585 \\
\hline Market_Volatility & 0.166 & 0.077 & 0.108 & 0.158 & 0.220 & 44,673 \\
\hline Market_Upswing & 0.754 & 0.431 & 1.000 & 1.000 & 1.000 & 44,673 \\
\hline Prior_M\&A_Activity & 0.274 & 0.446 & 0.000 & 0.000 & 1.000 & 44,673 \\
\hline Panel B: Combined sample & & & & & & \\
\hline Compensation Variables & & & & & & \\
\hline Delta $(\$ 000 \mathrm{~s})$ & 1,875 & 19,207 & 62 & 210 & 646 & 10,684 \\
\hline Vega (\$000s) & 167 & 444 & 7 & 40 & 148 & 10,684 \\
\hline Cash_Comp (\$000s) & 1,579 & 2,333 & 649 & 1,017 & 1,718 & 10,684 \\
\hline New_Grants (\$000s) & 4,551 & 13,654 & 275 & 1,500 & 4,447 & 10,684 \\
\hline Total_Comp (\$000s) & 6,951 & 14,641 & 1,598 & 3,316 & 7,404 & 10,684 \\
\hline
\end{tabular}

This article is protected by copyright. All rights reserved. 


\begin{tabular}{|l|r|r|r|r|r|c|}
\hline Deal \& Firm Characteristics & & & & & & \\
\hline Herding & 0.491 & 0.500 & 0.000 & 0.000 & 1.000 & 3,312 \\
\hline Size & 3.421 & 0.794 & 2.840 & 3.360 & 3.930 & 10,585 \\
\hline Payment_Cash & 0.558 & 0.497 & 0.000 & 1.000 & 1.000 & 10,684 \\
\hline Diversifying & 0.407 & 0.491 & 0.000 & 0.000 & 1.000 & 10,655 \\
\hline Runup & 0.042 & 0.755 & -0.205 & 0.035 & 0.296 & 10,113 \\
\hline Cash/Assets & 0.146 & 0.171 & 0.025 & 0.074 & 0.208 & 10,552 \\
\hline Public & 0.216 & 0.412 & 0.000 & 0.000 & 0.000 & 10,684 \\
\hline Private & 0.446 & 0.497 & 0.000 & 0.000 & 1.000 & 10,684 \\
\hline Relative_Size & 0.132 & 0.414 & 0.013 & 0.041 & 0.119 & 10,323 \\
\hline B/M & 0.616 & 0.288 & 0.410 & 0.610 & 0.830 & 10,527 \\
\hline Distance & 875 & 823 & 187 & 626 & 1,404 & 8,852 \\
\hline Speed & 0.187 & 0.252 & 0.000 & 0.115 & 0.271 & 10,684 \\
\hline Prior_M\&A_Activity & 0.564 & 0.496 & 0.000 & 1.000 & 1.000 & 10,684 \\
\hline No_Bidders & 1.012 & 0.127 & 1.000 & 1.000 & 1.000 & 10,684 \\
\hline Overvaluation & 0.548 & 0.498 & 0.000 & 1.000 & 1.000 & 10,400 \\
\hline Sales_Shock & -0.010 & 0.293 & -0.129 & 0.011 & 0.154 & 10,400 \\
\hline Emp_Shock & 0.018 & 0.266 & -0.083 & 0.046 & 0.150 & 10,400 \\
\hline Market_Volatility & 0.167 & 0.072 & 0.111 & 0.159 & 0.195 & 10,400 \\
\hline Market_Upswing & 0.781 & 0.414 & 1.000 & 1.000 & 1.000 & 10,684 \\
\hline Tabl_2:Differencen
\end{tabular}

Table 2: Difference in CEO compensation between in-wave and out-of-wave acquirers

The table presents differences in CEO compensation incentives between in-wave and out-of-wave acquiring firms. The sample is 10,684 completed U.S. acquisitions over the period January 1, 1993, to December 31, 2016 from SDC Platinum. Data on executive compensation are from ExecuComp. Delta is the dollar change in CEO's wealth for a 1 percent change in firm's stock price. Vega is the dollar change in CEO's wealth for a 1 percent change in the standard deviation of firm's stock returns. Cash_Comp is the sum of CEO's salary and bonus. Total_Comp is the sum of CEO's salary, bonus, new stock and option grants and other forms of compensation. Transactions are classified as in-wave or out-of-wave following the method developed by Harford (2005). t-statistics are from the t-test for difference in means and $z$-statistics are from the Wilcoxon rank sum test for difference between the respective distributions. ${ }^{* * *}, * *$, and $*$ indicate statistical significance at the $1 \%, 5 \%$ and $10 \%$ level respectively.

\begin{tabular}{|c|c|c|c|c|}
\hline \multicolumn{5}{|c|}{ Panel A: Compensation Characteristics (\$000s) } \\
\hline & In-Wave & Out-of-Wave & Difference & t/z statistic \\
\hline \multicolumn{5}{|l|}{ Delta } \\
\hline Mean & $2,392.87$ & $1,618.06$ & 774.81* & 1.77 \\
\hline Median & 229.62 & 198.29 & $31.33^{* * *}$ & 3.61 \\
\hline Observations & 3,312 & 7,372 & & \\
\hline \multicolumn{5}{|l|}{ Vega } \\
\hline Mean & 149.91 & 172.74 & $-22.82 * * *$ & -2.65 \\
\hline Median & 35.34 & 41.96 & $-6.62 * * *$ & -4.39 \\
\hline Observations & 3,312 & 7,372 & & \\
\hline \multicolumn{5}{|l|}{ Cash_Comp } \\
\hline Mean & $1,675.20$ & $1,535.94$ & $139.26^{* *}$ & 2.54 \\
\hline Median & $1,032.17$ & $1,012.79$ & 19.38 & 0.14 \\
\hline Observations & 3,312 & 7,372 & & \\
\hline \multicolumn{5}{|c|}{ Panel B: Compensation Incentives scaled by Total Compensation } \\
\hline & In-Wave & Out-of-Wave & Difference & t/z statistic \\
\hline \multicolumn{5}{|l|}{ Delta / Total_Comp } \\
\hline Mean & 2.851 & 1.164 & $1.687 * *$ & 2.13 \\
\hline Median & 0.061 & 0.052 & $0.009^{* * *}$ & 5.10 \\
\hline Observations & 3,312 & 7,372 & & \\
\hline Vega / Total Comp & & & & \\
\hline
\end{tabular}

This article is protected by copyright. All rights reserved. 


\begin{tabular}{|l|c|c|c|c|}
\hline Mean & 0.022 & 0.030 & $-0.008^{* *}$ & -2.13 \\
\hline Median & 0.011 & 0.013 & $-0.002^{* * *}$ & -7.52 \\
\hline Observations & 3,312 & 7,372 & & \\
\hline Cash_Comp / Total_Comp & & & & \\
\hline Mean & 0.445 & 0.416 & $0.029^{* * *}$ & 4.59 \\
\hline Median & 0.383 & 0.340 & $0.042^{* * *}$ & 4.36 \\
\hline Observations & 3,312 & 7,372 & & \\
\hline & & & & \\
\hline
\end{tabular}

Table 3: Compensation incentives and the propensity to acquire

The table presents the results of probit regressions for the extended ExecuComp sample of 44,673 firm-year observations over the period 1992-2015. Executive compensation data are from ExecuComp, stock price data from CRSP and accounting data from Compustat. The dependent variable, Acquisition, takes the value of one if a firm makes an acquisition announcement in a given year and zero otherwise. In-Wave_Year is a dummy variable that takes the value of one if the industry experiences a merger wave during the calendar year and zero otherwise. Merger waves are identified based on the method developed by Harford (2005). Delta is the dollar change in CEO's wealth for a 1 percent change in firm's stock price. Vega is the dollar change in CEO's wealth for a 1 percent change in the standard deviation of firm's stock returns. S_Cash_Comp is the sum of CEO's salary and bonus standardized by total compensation. Definitions of control variables are described in Appendix A. Compensation and control variables are defined at the year before the acquisition announcement. z-statistics, based on robust standard errors clustered at the firm level, are reported in parentheses. $* * *, * *$, and * indicate statistical significance at the $1 \%, 5 \%$ and $10 \%$ level respectively.

\begin{tabular}{|c|c|c|c|}
\hline Variable & $\begin{array}{c}\text { Model } 1 \\
\text { All }\end{array}$ & $\begin{array}{c}\text { Model } 2 \\
\text { In-Wave Year }\end{array}$ & $\begin{array}{c}\text { Model } 3 \\
\text { Out-of-Wave Year }\end{array}$ \\
\hline \multirow[t]{2}{*}{ Intercept } & $-1.3536 * * *$ & $-1.1013 * * *$ & $-1.3977 * * *$ \\
\hline & $(-16.01)$ & $(-6.84)$ & $(-15.04)$ \\
\hline \multirow{2}{*}{ Delta } & 0.0010 & 0.0010 & 0.0021 \\
\hline & $(0.79)$ & $(1.17)$ & $(0.93)$ \\
\hline \multirow[t]{2}{*}{ Vega } & $0.1337^{* * *}$ & 0.0250 & $0.1825 * * *$ \\
\hline & $(3.26)$ & $(0.48)$ & $(4.38)$ \\
\hline \multirow{2}{*}{ S_Cash_Comp } & $-0.1235 * * *$ & $-0.1389 * *$ & $-0.1172 * * *$ \\
\hline & $(-3.87)$ & $(-2.52)$ & $(-3.19)$ \\
\hline \multirow[t]{2}{*}{ In-Wave_Year } & $0.0973 * * *$ & & \\
\hline & $(5.85)$ & & \\
\hline \multirow[t]{2}{*}{ Size } & $0.1488^{* * *}$ & $0.0884 * * *$ & $0.1713 * * *$ \\
\hline & $(7.42)$ & $(3.06)$ & $(7.74)$ \\
\hline \multirow[t]{2}{*}{ Past_ABHR } & $0.0484 * * *$ & $0.0920 * * *$ & $0.0266^{*}$ \\
\hline & $(4.00)$ & $(4.40)$ & $(1.77)$ \\
\hline \multirow[t]{2}{*}{ Cash/Assets } & -0.0306 & $-0.2249 * *$ & -0.0130 \\
\hline & $(-0.46)$ & $(-2.15)$ & $(-0.17)$ \\
\hline \multirow[t]{2}{*}{$\mathrm{B} / \mathrm{M}$} & $-0.1305 * * *$ & $-0.2001 * * *$ & $-0.1105^{* * *}$ \\
\hline & $(-4.65)$ & $(-3.25)$ & $(-4.13)$ \\
\hline \multirow[t]{2}{*}{ ROA } & $0.4147 * * *$ & $0.5838^{* * *}$ & $0.3489 * * *$ \\
\hline & $(4.36)$ & $(3.70)$ & $(3.31)$ \\
\hline \multirow[t]{2}{*}{ Sales_Growth } & $0.4426^{* * *}$ & $0.2673 * *$ & $0.5194 * * *$ \\
\hline & $(6.00)$ & $(2.05)$ & $(5.96)$ \\
\hline Leverage & $-0.2937 * * *$ & -0.1175 & $-0.3505^{* * *}$ \\
\hline & $(-4.78)$ & $(-1.12)$ & $(-5.14)$ \\
\hline $\mathrm{P} / \mathrm{E}$ & -0.0018 & 0.0026 & -0.0041 \\
\hline & $(-0.41)$ & $(0.37)$ & $(-0.75)$ \\
\hline NC_Working_Cap & $0.3217^{* * * *}$ & $0.4114 * * *$ & $0.2507 * * *$ \\
\hline & $(5.01)$ & $(4.24)$ & $(3.57)$ \\
\hline Overvaluation & -0.0057 & 0.0582 & -0.0149 \\
\hline & $(-0.30)$ & $(1.55)$ & $(-0.67)$ \\
\hline
\end{tabular}

This article is protected by copyright. All rights reserved. 


\begin{tabular}{|l|c|c|c|}
\hline Sales_Shock & -0.0331 & 0.1193 & -0.0489 \\
\hline & $(-0.72)$ & $(1.00)$ & $(-0.98)$ \\
\hline Emp_Shock & 0.0782 & 0.1712 & 0.0454 \\
\hline & $(1.49)$ & $(1.21)$ & $(0.80)$ \\
\hline Market_Volatility & 0.1527 & $1.2151^{* * *}$ & 0.0060 \\
\hline & $(1.20)$ & $(2.76)$ & $(0.04)$ \\
\hline Market_Upswing & $0.0730^{* * *}$ & $-0.1107^{*}$ & $0.0990^{* * *}$ \\
\hline & $(3.82)$ & $(-1.85)$ & $(4.69)$ \\
\hline Prior_M\&A_Activity & $0.8108^{* * *}$ & $0.8652^{* * *}$ & $0.7811^{* * *}$ \\
\hline & $(36.23)$ & $(24.18)$ & $(31.64)$ \\
\hline Number of Observations & 33,062 & 8,556 & 24,506 \\
\hline Wald Chi-Square & $1904.28^{* * *}$ & $849.04^{* * *}$ & $1464.27^{* * *}$ \\
\hline Pseudo R-Square & 0.092 & 0.105 & 0.088 \\
\hline
\end{tabular}

Table 4: Changes in CEO compensation surrounding mergers conditional on merger waves

The table presents changes in CEO compensation surrounding mergers conditional on merger waves. The sample is 10,684 completed U.S. acquisitions over the period January 1, 1993, to December 31, 2016 from SDC Platinum. Data on executive compensation are from ExecuComp. Panel A presents compensation at the yearend prior to the merger announcement $(\mathrm{t}-1)$. Panel $\mathrm{B}$ presents compensation at the year-end following completion of the merger $(t+1)$. Panel $\mathrm{C}$ presents changes in compensation from $\mathrm{t}-1$ to $\mathrm{t}+1$. Cash compensation is the sum of CEO's salary and cash bonuses. New_Grants are the sum of the Black-Scholes fair value of new option and stock grants awarded to the CEO during the year. Total compensation is the sum of CEO's cash compensation, new grants and other forms of compensation. All figures are expressed in $\$ 000$ s. t-statistics are from the t-test for difference in means and $z$-statistics are from the Wilcoxon rank sum test for difference between the respective distributions. ${ }^{* *},{ }^{* *}$, and $*$ indicate statistical significance at the $1 \%, 5 \%$ and $10 \%$ level respectively.

\begin{tabular}{|c|c|c|c|c|}
\hline & \multicolumn{3}{|c|}{ Panel A: t-1 } & \multirow[b]{2}{*}{ t/z statistic } \\
\hline & In-Wave & Out-of-Wave & Difference & \\
\hline Observations & 3,312 & 7,372 & & \\
\hline \multicolumn{5}{|l|}{ Cash Comp } \\
\hline Mean & $1,675.20$ & $1,535.94$ & $139.26^{* *}$ & 2.54 \\
\hline Median & $1,032.17$ & $1,012.79$ & 19.38 & 0.14 \\
\hline \multicolumn{5}{|l|}{ New_Grants } \\
\hline Mean & $5,594.56$ & $4,081.99$ & $1,512.57 * * *$ & 4.08 \\
\hline Median & $1,387.02$ & $1,544.43$ & -157.42 & 1.19 \\
\hline \multicolumn{5}{|l|}{ Total_Comp } \\
\hline Mean & $7,935.71$ & $6,508.24$ & $1,427.47 * * *$ & 3.68 \\
\hline \multirow[t]{3}{*}{ Median } & $3,150.63$ & $3,407.88$ & $-257.24 * *$ & 2.03 \\
\hline & \multicolumn{3}{|c|}{ Panel B: $t+1$} & \\
\hline & In-Wave & Out-of-Wave & Difference & t/z statistic \\
\hline Observations & 2.779 & 6,343 & & \\
\hline \multicolumn{5}{|l|}{ Cash_Comp } \\
\hline Mean & $1,591.21$ & $1,593.21$ & 2.00 & 0.04 \\
\hline Median & $1,028.23$ & $1,027.37$ & -0.86 & -1.27 \\
\hline \multicolumn{5}{|l|}{ New_Grants } \\
\hline Mean & $7,642.81$ & $4,687.24$ & $2,955.57 * * *$ & 6.72 \\
\hline Median & $1,888.94$ & $1,925.26$ & -36.32 & -1.19 \\
\hline \multicolumn{5}{|l|}{ Total_Comp } \\
\hline Mean & $10,090.17$ & $7,358.20$ & $2,731.97 * * *$ & 5.93 \\
\hline Median & $3,893.93$ & $3,970.43$ & -76.50 & -0.21 \\
\hline
\end{tabular}

This article is protected by copyright. All rights reserved. 


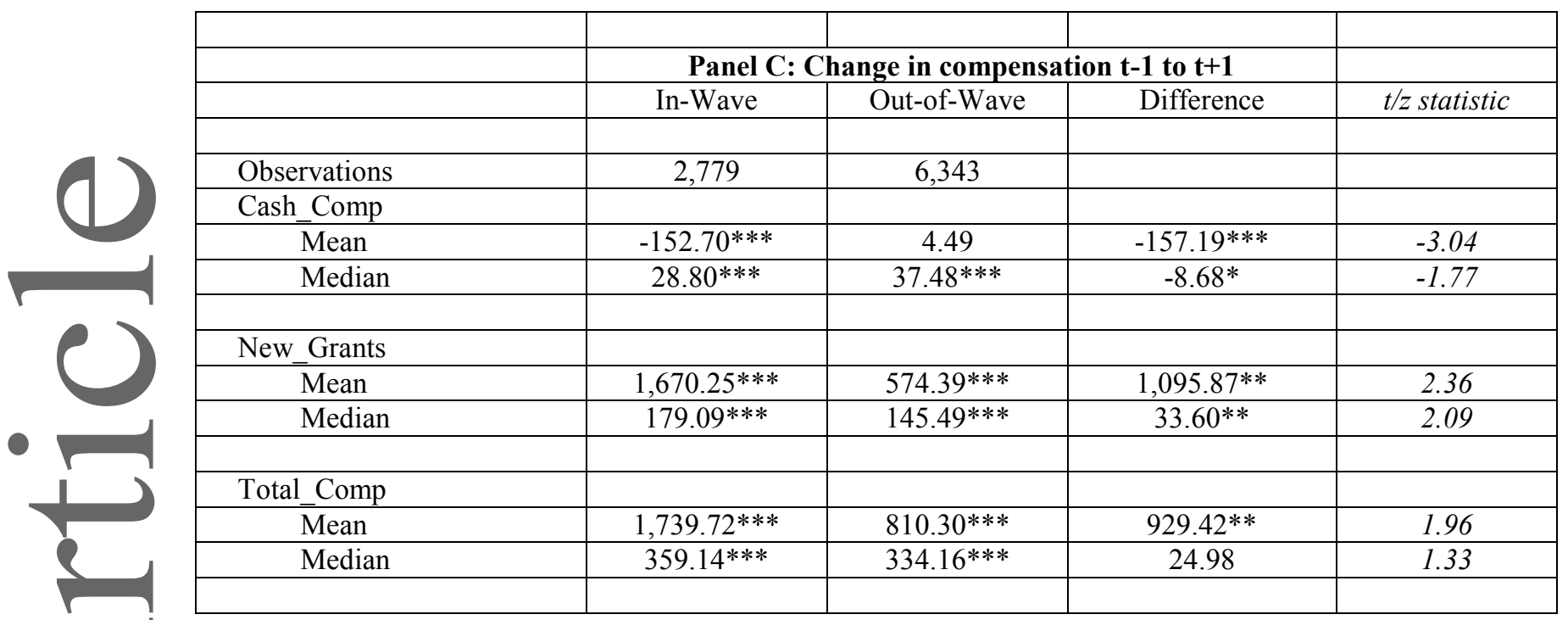

\section{Table 5: Merger waves and deal performance}

The table presents differences in acquisition performance between in-wave and out-of-wave acquiring firms. The sample is 10,684 completed U.S. acquisitions over the period January 1, 1993, to December 31, 2016 from SDC Platinum. Stock price data are from CRSP and accounting data from Compustat. CARs $(0.1)$ is the bidder's cumulative abnormal returns over a two-day event window $(0,+1)$ where 0 is the acquisition announcement date using the market model. The estimation period is from 200 days to 60 days before the acquisition announcement. Market returns are based on the CRSP value-weighted index. 2yABHR is the bidder's 2-year buy-and-hold daily returns following the acquisition effective date minus the 2-year buy-and-hold daily returns of the matched firm for the same period. 2yABHR_PSM is the bidder's 2-year buy-and-hold daily returns following the acquisition effective date minus the 2-year buy-and-hold daily returns of the propensity-score matched firm for the same time period from CRSP. $D \_R O A$ is the difference between the acquirer's return on assets (ROA) at the end of the second year following the effective date $(\mathrm{t}+2)$ and the acquirer's ROA at the year of the acquisition effective day ( $\mathrm{t})$. $D_{-} R O A_{-} P S M$ is the difference between the acquirer's return on assets (ROA) at the end of the second year following the effective date $(\mathrm{t}+2)$ and the acquirer's ROA at the year of the acquisition effective date $(t)$ minus the change in ROA of the propensity-score matched firm for the same time period from Compustat. Transactions are classified as in-wave or out-of-wave following the method developed by Harford (2005).***,**, and * indicate statistical significance at the $1 \%, 5 \%$ and $10 \%$ level respectively.

\begin{tabular}{|c|c|c|c|c|}
\hline \multicolumn{5}{|c|}{ Panel A: CARs $(0,1)$} \\
\hline & Full Sample & In-Wave & Out-of-Wave & $\begin{array}{c}\text { Difference } \\
\text { In VS Out-of-Wave }\end{array}$ \\
\hline Mean & $0.34 * * *$ & $0.28 * * *$ & $0.36^{* * *}$ & -0.08 \\
\hline Median & $0.12^{* * *}$ & $0.01 *$ & $0.19 * * *$ & $-0.19 * *$ \\
\hline Observations & 9,886 & 3,099 & 6,787 & \\
\hline \multicolumn{5}{|c|}{ Panel B: 2yABHR } \\
\hline & Full Sample & In-Wave & Out-of-Wave & $\begin{array}{c}\text { Difference } \\
\text { In VS Out-of-Wave }\end{array}$ \\
\hline Mean & $3.40 * * *$ & -1.60 & $5.46^{* * *}$ & $-7.07 * * *$ \\
\hline Median & $2.43 * * *$ & -0.61 & $4.23 * * *$ & $-4.84 * * *$ \\
\hline Observations & 8,393 & 2,447 & 5,946 & \\
\hline \multicolumn{5}{|c|}{ Panel C: 2yABHR_PSM } \\
\hline & Full Sample & In-Wave & Out-of-Wave & $\begin{array}{c}\text { Difference } \\
\text { In VS Out-of-Wave }\end{array}$ \\
\hline Mean & $2.23 * *$ & $-2.81 *$ & $4.32 * * *$ & $-7.13 * * *$ \\
\hline Median & $2.28 * * *$ & -1.18 & $3.82^{* * *}$ & $-5.00 * * *$ \\
\hline
\end{tabular}

This article is protected by copyright. All rights reserved. 


\begin{tabular}{|l|c|c|c|c|}
\hline Observations & 6,470 & 1,896 & 4,574 & \\
\hline & \multicolumn{4}{|c|}{ Panel D: D_ROA } \\
\hline & Full Sample & In-Wave & Out-of-Wave & $\begin{array}{c}\text { Difference } \\
\text { In VS Out-of-Wave }\end{array}$ \\
\hline & & & & $-2.36^{* * *}$ \\
\hline Mean & $-1.10^{* * *}$ & $-2.79^{* * *}$ & $-0.42^{* * *}$ & $-0.60^{* * *}$ \\
\hline Median & $-0.11^{* * *}$ & $-0.59^{* * *}$ & $0.01^{* *}$ & \\
\hline Observations & 7,878 & 2,260 & 5,618 & \\
\hline \multicolumn{5}{|c|}{ Panel E: D_ROA_PSM } \\
\hline & Full Sample & In-Wave & Out-of-Wave & $\begin{array}{c}\text { Difference } \\
\text { In VS Out-of-Wave }\end{array}$ \\
\hline & $0.78^{* * *}$ & 0.14 & $1.04^{* * *}$ & $-0.91^{* * *}$ \\
\hline Mean & $0.36^{* * *}$ & 0.13 & $0.44^{* * *}$ & $-0.31^{* * *}$ \\
\hline Median & 6,151 & 1,769 & 4,382 & \\
\hline Observations & \multicolumn{7}{|c|}{} \\
\hline
\end{tabular}

Table 6: Acquiring firm announcement returns, merger waves and CEO compensation

The table presents multivariate regression results of bidder's two-day CARs (0.1) on CEO compensation and other firm and deal characteristics. The sample is 10,684 completed U.S. acquisitions over the period January 1 , 1993, to December 31, 2016 from SDC Platinum. Data on executive compensation are from ExecuComp, stock price data from CRSP and accounting data from Compustat. The dependent variable CARs $(0.1)$ is the bidder's cumulative abnormal returns over a two-day event window $(0,+1)$ where 0 is the acquisition announcement date using the market model. The estimation period is from 200 days to 60 days before the acquisition announcement. Market returns are based on the CRSP value-weighted index. Delta is the dollar change in CEO's wealth for a 1 percent change in firm's stock price. Vega is the dollar change in CEO's wealth for a 1 percent change in the standard deviation of firm's stock returns. S_Cash_Comp is the sum of CEO's salary and bonus standardized by total compensation. In_Wave is a dummy variable that takes the value of one if the acquisition has been initiated during a merger wave and zero otherwise. Transactions are classified as in-wave or out-of-wave following the method developed by Harford (2005). Definitions of control variables are described in Appendix A. Compensation and control variables are defined at the year before the acquisition announcement. t-statistics, based on robust standard errors clustered at the firm level, are reported in parentheses. ${ }^{* *}, * *$, and $*$ indicate statistical significance at the $1 \%, 5 \%$ and $10 \%$ level respectively.

\begin{tabular}{|l|c|c|c|}
\hline Variable & $\begin{array}{c}\text { Model 1 } \\
\text { Total Sample }\end{array}$ & $\begin{array}{c}\text { Model 2 } \\
\text { In-Wave }\end{array}$ & $\begin{array}{c}\text { Model 3 } \\
\text { Out-of-Wave }\end{array}$ \\
\hline Intercept & $2.7948^{* * *}$ & $4.1661^{* * *}$ & $2.4555^{* * *}$ \\
\hline & $(4.53)$ & $(3.11)$ & $(3.43)$ \\
\hline Delta & $0.0030^{* * *}$ & $0.0041^{* * *}$ & $0.0023^{* *}$ \\
\hline Vega & $(3.41)$ & $(3.59)$ & $(2.27)$ \\
\hline & $0.2366^{* *}$ & 0.0664 & $0.2884^{* * *}$ \\
\hline S_Cash_Comp & $(2.52)$ & $(0.41)$ & $(3.07)$ \\
\hline & -0.1410 & -0.1538 & -0.1080 \\
\hline In_Wave & $(-0.75)$ & $(-0.44)$ & $(-0.47)$ \\
\hline & 0.0097 & & \\
\hline Herding & $(0.09)$ & -0.2025 & $-0.4274^{* * *}$ \\
\hline & & $(-1.03)$ & $(-4.57)$ \\
\hline Size & & $-0.5685^{* * *}$ & $0.3623^{* * *}$ \\
\hline & $-0.4804^{* * *}$ & $(-3.86)$ & $(3.03)$ \\
\hline Payment_Cash & $(-6.01)$ & $0.5858^{* * *}$ & $-0.2262^{*}$ \\
\hline & $0.4348^{* * *}$ & $(2.92)$ & $(-1.92)$ \\
\hline Diversifying & $(4.37)$ & 0.2587 & $-0.2690^{* *}$ \\
\hline & -0.0791 & $(1.38)$ & -0.2163 \\
\hline Runup & $(-0.79)$ & &
\end{tabular}

This article is protected by copyright. All rights reserved. 


\begin{tabular}{|c|c|c|c|}
\hline & $(-2.74)$ & $(-1.59)$ & $(-2.24)$ \\
\hline Cash/Assets & $-1.1598 * * *$ & -0.6061 & $-1.3608 * * *$ \\
\hline & $(-2.99)$ & $(-0.94)$ & $(-2.98)$ \\
\hline Public & $-1.1645 * * *$ & $-1.0190 * * *$ & $-1.2262 * * *$ \\
\hline & $(-7.77)$ & $(-3.63)$ & $(-7.23)$ \\
\hline Private & -0.0734 & -0.1760 & -0.0209 \\
\hline & $(-0.67)$ & $(-0.84)$ & $(-0.16)$ \\
\hline Relative_Size & -0.0137 & 0.2459 & -0.0441 \\
\hline & $(-0.10)$ & $(0.53)$ & $(-0.29)$ \\
\hline $\mathrm{B} / \mathrm{M}$ & -0.0345 & -0.4786 & 0.1429 \\
\hline & $(-0.17)$ & $(-1.22)$ & $(0.58)$ \\
\hline Overvaluation & -0.1030 & -0.3901 & -0.0122 \\
\hline & $(-0.88)$ & $(-1.45)$ & $(-0.09)$ \\
\hline Sales_Shock & $0.3133^{*}$ & 0.5267 & $0.3828^{* *}$ \\
\hline & $(1.91)$ & $(1.06)$ & $(2.19)$ \\
\hline Emp_Shock & -0.2864 & -0.4376 & -0.2711 \\
\hline & $(-1.39)$ & $(-0.76)$ & $(-1.24)$ \\
\hline Market_Volatility & -1.0739 & -4.8012 & -0.6461 \\
\hline & $(-1.30)$ & $(-1.62)$ & $(-0.73)$ \\
\hline Market_Upswing & 0.0865 & -0.0782 & 0.1380 \\
\hline & $(0.67)$ & $(-0.24)$ & $(0.96)$ \\
\hline Prior_M\&A_Activity & -0.0682 & -0.1463 & -0.0319 \\
\hline & $(-0.66)$ & $(-0.79)$ & $(-0.27)$ \\
\hline Distance & 0.0144 & 0.1015 & -0.0241 \\
\hline & $(0.23)$ & $(0.85)$ & $(-0.35)$ \\
\hline Speed & 0.0373 & 0.4681 & -0.0823 \\
\hline & $(0.17)$ & $(0.80)$ & $(-0.40)$ \\
\hline No_Bidders & -0.3046 & -0.5171 & -0.2822 \\
\hline & $(-0.69)$ & $(-0.59)$ & $(-0.53)$ \\
\hline Number of Observations & 8,082 & 2,344 & 5,738 \\
\hline F-Statistic & $11.21^{* * *}$ & $5.05 * * *$ & $8.72 * * *$ \\
\hline R-Squared & 0.032 & 0.040 & 0.032 \\
\hline
\end{tabular}

Table 7: Acquiring firm long-run stock price performance, merger waves and CEO compensation

The table presents multivariate regression results of acquisition long-run financial performance on CEO compensation and other firm and deal characteristics. The sample is 10,684 completed U.S. acquisitions over the period January 1, 1993, to December 31, 2016 from SDC Platinum. Data on executive compensation are from ExecuComp, stock price data from CRSP and accounting data from Compustat. $2 y A B H R$ is the bidder's 2-year buy-and-hold daily returns following the acquisition effective date minus the 2-year buy-and-hold daily returns of the matched firm for the same period. 2yABHR_PSM is the bidder's 2-year buy-and-hold daily returns following the acquisition effective date minus the 2-year buy-and-hold daily returns of the propensity-score matched firm for the same time period from CRSP. Delta is the dollar change in CEO's wealth for a 1 percent change in firm's stock price. Vega is the dollar change in CEO's wealth for a 1 percent change in the standard deviation of firm's stock returns. S_Cash_Comp is the sum of CEO's salary and bonus standardized by total compensation. In_Wave is a dummy variable that takes the value of one if the acquisition has been initiated during a merger wave and zero otherwise. Transactions are classified as in-wave or out-of-wave following the method developed by Harford (2005). Definitions of control variables are described in Appendix A. Compensation and control variables are defined at the year before the acquisition announcement. t-statistics, based on robust standard errors clustered at the firm level, are reported in parentheses. ***, **, and * indicate statistical significance at the $1 \%, 5 \%$ and $10 \%$ level respectively.

\begin{tabular}{|l|c|c|c|c|c|c|}
\hline & \multicolumn{3}{|c|}{ 2yABHR } & \multicolumn{3}{|c|}{ 2yABHR_PSM } \\
\hline Variable & $\begin{array}{c}\text { Model 1 } \\
\text { Total } \\
\text { Sample }\end{array}$ & $\begin{array}{c}\text { Model 2 } \\
\text { In-Wave }\end{array}$ & $\begin{array}{c}\text { Model 3 } \\
\text { Out-of- } \\
\text { Wave }\end{array}$ & $\begin{array}{c}\text { Model 4 } \\
\text { Total } \\
\text { Sample }\end{array}$ & $\begin{array}{c}\text { Model 5 } \\
\text { In-Wave }\end{array}$ & $\begin{array}{c}\text { Model 6 } \\
\text { Out-of- } \\
\text { Wave }\end{array}$ \\
\hline Intercept & & & & & & \\
\hline & $0.3036^{*}$ & 0.0202 & $0.3161^{*}$ & -0.0092 & -0.2353 & -0.0682 \\
\hline Delta & $(1.81)$ & $(0.06)$ & $(1.80)$ & $(-0.05)$ & $(-0.56)$ & $(-0.36)$ \\
\hline
\end{tabular}

This article is protected by copyright. All rights reserved. 


\begin{tabular}{|c|c|c|c|c|c|c|}
\hline & $(6.82)$ & $(3.25)$ & $(6.12)$ & $(1.93)$ & $(1.95)$ & $(3.17)$ \\
\hline Vega & $0.0501^{* *}$ & 0.0124 & $0.0696^{* * *}$ & 0.0113 & -0.0009 & 0.0102 \\
\hline & $(2.19)$ & $(0.25)$ & $(2.61)$ & $(0.33)$ & $(-0.01)$ & $(0.29)$ \\
\hline S_Cash_Comp & 0.0105 & 0.0107 & 0.0028 & 0.0857 & 0.1277 & 0.0617 \\
\hline & $(0.15)$ & $(0.10)$ & $(0.03)$ & $(1.02)$ & $(0.97)$ & $(0.66)$ \\
\hline In Wave & $-0.0708^{*}$ & & & $-0.0755^{* * *}$ & & \\
\hline & $(-1.90)$ & & & $(-2.00)$ & & \\
\hline Herding & & $-0.1374 * *$ & & & -0.0073 & \\
\hline & & $(-2.17)$ & & & $(-0.08)$ & \\
\hline Size & $-0.1010 * * *$ & $-0.0968^{*}$ & $-0.1070 * * *$ & -0.0538 & -0.0437 & -0.0584 \\
\hline & $(-3.21)$ & $(-1.68)$ & $(-3.07)$ & $(-1.39)$ & $(-0.48)$ & $(-1.40)$ \\
\hline Payment_Cash & 0.0438 & -0.0779 & $0.0973^{* *}$ & 0.0555 & -0.0095 & $0.0812^{* *}$ \\
\hline & $(1.18)$ & $(-1.12)$ & $(2.39)$ & $(1.59)$ & $(-0.16)$ & $(2.01)$ \\
\hline Diversifying & -0.0145 & -0.0264 & -0.0140 & 0.0334 & 0.0070 & 0.0404 \\
\hline & $(-0.39)$ & $(-0.50)$ & $(-0.32)$ & $(0.93)$ & $(0.11)$ & $(0.97)$ \\
\hline Runup & 0.0018 & $-0.1045 * * *$ & 0.0640 & -0.0503 & $-0.1391 * * *$ & -0.0046 \\
\hline & $(0.05)$ & $(-2.94)$ & $(1.30)$ & $(-1.48)$ & $(-2.98)$ & $(-0.11)$ \\
\hline Cash/Assets & 0.0079 & -0.0268 & 0.0665 & 0.0762 & 0.0123 & 0.1039 \\
\hline & $(0.06)$ & $(-0.14)$ & $(0.39)$ & $(0.51)$ & $(0.04)$ & $(0.60)$ \\
\hline $\begin{array}{l}\text { Public } \\
\end{array}$ & $-0.1132 * *$ & -0.1159 & $-0.1186^{* *}$ & -0.0379 & -0.0852 & -0.0233 \\
\hline & $(-2.34)$ & $(-1.26)$ & $(-2.19)$ & $(-0.76)$ & $(-0.81)$ & $(-0.45)$ \\
\hline Private & $-0.0840^{* *}$ & $-0.1601 * *$ & -0.0582 & -0.0615 & $-0.1215^{*}$ & -0.0402 \\
\hline & $(-2.19)$ & $(-2.31)$ & $(-1.44)$ & $(-1.48)$ & $(-1.75)$ & $(-0.85)$ \\
\hline Relative_Size & 0.0217 & -0.0928 & 0.0512 & 0.0746 & -0.0143 & 0.0958 \\
\hline & $(0.35)$ & $(-0.77)$ & $(0.76)$ & $(1.25)$ & $(-0.11)$ & $(1.44)$ \\
\hline $\mathrm{B} / \mathrm{M}$ & 0.1002 & 0.1617 & 0.0929 & 0.0516 & 0.1223 & 0.0431 \\
\hline & $(1.21)$ & $(1.36)$ & $(0.98)$ & $(0.56)$ & $(0.98)$ & $(0.38)$ \\
\hline Overvaluation & -0.0202 & -0.0221 & -0.0487 & -0.0069 & -0.0302 & 0.0060 \\
\hline & $(-0.53)$ & $(-0.24)$ & $(-1.08)$ & $(-0.13)$ & $(-0.25)$ & $(0.10)$ \\
\hline Sales_Shock & -0.0396 & -0.0226 & -0.0682 & 0.0473 & -0.0281 & 0.0556 \\
\hline & $(-0.70)$ & $(-0.16)$ & $(-1.13)$ & $(0.90)$ & $(-0.20)$ & $(0.95)$ \\
\hline Emp_Shock & $0.0883^{*}$ & $0.2382 *$ & 0.0664 & -0.0076 & 0.1378 & -0.0284 \\
\hline & $(1.74)$ & $(1.87)$ & $(1.19)$ & $(-0.15)$ & $(1.19)$ & $(-0.51)$ \\
\hline Market_Volatility & -0.0543 & 1.2479 & -0.1402 & 0.2540 & 1.4067 & 0.2010 \\
\hline & $(-0.22)$ & $(1.27)$ & $(-0.56)$ & $(0.80)$ & $(1.19)$ & $(0.62)$ \\
\hline Market_Upswing & $0.1150 * * *$ & $0.3448 * * *$ & 0.0535 & $0.0740^{*}$ & $0.2004 *$ & 0.0529 \\
\hline & $(2.72)$ & $(3.45)$ & $(1.25)$ & $(1.82)$ & $(1.76)$ & $(1.18)$ \\
\hline Prior_M\&A_Activity & 0.0003 & -0.0476 & 0.0171 & 0.0365 & -0.0312 & 0.0585 \\
\hline & $(0.01)$ & $(-0.77)$ & $(0.41)$ & $(0.87)$ & $(-0.39)$ & $(1.25)$ \\
\hline Distance & 0.0181 & 0.0002 & 0.0265 & 0.0097 & -0.0021 & 0.0153 \\
\hline & $(1.01)$ & $(0.01)$ & $(1.29)$ & $(0.45)$ & $(-0.05)$ & $(0.62)$ \\
\hline Speed & -0.0159 & -0.3000 & 0.0732 & -0.0048 & -0.2291 & 0.0701 \\
\hline & $(-0.19)$ & $(-1.30)$ & $(1.01)$ & $(-0.06)$ & $(-1.56)$ & $(0.82)$ \\
\hline No_Bidders & -0.0335 & 0.0209 & -0.0316 & -0.0036 & -0.0209 & 0.0353 \\
\hline & $(-0.50)$ & $(0.17)$ & $(-0.42)$ & $(-0.05)$ & $(-0.15)$ & $(0.42)$ \\
\hline Number of Observations & 6,915 & 1,827 & 5,088 & 5,482 & 1,492 & 3,990 \\
\hline & 4 & 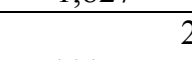 & 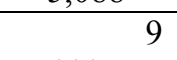 & & & \\
\hline F-Statistic & $.84 * * *$ & $.58 * * *$ & $.45^{* * *}$ & 1.38 & $.63 * *$ & 1.37 \\
\hline R-Squared & 0.010 & 0.032 & 0.010 & 0.006 & 0.015 & 0.006 \\
\hline
\end{tabular}

This article is protected by copyright. All rights reserved. 
Table 8: Acquiring firm long-run operating performance, merger waves and CEO compensation

The table presents multivariate regression results of acquisition long-run operating performance on CEO compensation and other firm and deal characteristics. The sample is 10,684 completed U.S. acquisitions over the period January 1, 1993, to December 31, 2016 from SDC Platinum. Data on executive compensation are from ExecuComp, stock price data from CRSP and accounting data from Compustat. D_ROA is the difference between the acquirer's return on assets (ROA) at the end of the second year following the effective date $(\mathrm{t}+2)$ and the acquirer's ROA at the year of the acquisition effective day $(\mathrm{t})$. D_ROA_PSM is the difference between the acquirer's return on assets (ROA) at the end of the second year following the effective date $(\mathrm{t}+2)$ and the acquirer's ROA at the year of the acquisition effective date $(\mathrm{t})$ minus the change in ROA of the propensity-score matched firm for the same time period from Compustat. Delta is the dollar change in CEO's wealth for a 1 percent change in firm's stock price. Vega is the dollar change in CEO's wealth for a 1 percent change in the standard deviation of firm's stock returns. S_Cash_Comp is the sum of CEO's salary and bonus standardized by total compensation. In_Wave is a dummy variable that takes the value of one if the acquisition has been initiated during a merger wave and zero otherwise. Transactions are classified as in-wave or out-of-wave following the method developed by Harford (2005). Definitions of control variables are described in Appendix A. Compensation and control variables are defined at the year before the acquisition announcement. t-statistics, based on robust standard errors clustered at the firm level, are reported in parentheses. ***, **, and * indicate statistical significance at the $1 \%, 5 \%$ and $10 \%$ level respectively.

\begin{tabular}{|c|c|c|c|c|c|c|}
\hline & \multicolumn{3}{|c|}{ D ROA } & \multicolumn{3}{|c|}{ D ROA PSM } \\
\hline Variable & $\begin{array}{c}\text { Model } 1 \\
\text { Total } \\
\text { Sample }\end{array}$ & $\begin{array}{l}\text { Model } 2 \\
\text { In-Wave }\end{array}$ & $\begin{array}{c}\text { Model } 3 \\
\text { Out-of- } \\
\text { Wave }\end{array}$ & $\begin{array}{c}\text { Model } 4 \\
\text { Total } \\
\text { Sample }\end{array}$ & $\begin{array}{l}\text { Model } 5 \\
\text { In-Wave }\end{array}$ & $\begin{array}{c}\text { Model } 6 \\
\text { Out-of- } \\
\text { Wave }\end{array}$ \\
\hline \multirow[t]{2}{*}{ Intercept } & $-2.9420 * * *$ & -0.2813 & $-2.7894 * * *$ & -1.1143 & $-7.9232 *$ & -0.2829 \\
\hline & $(-2.96)$ & $(-0.09)$ & $(-2.60)$ & $(-0.68)$ & $(-1.96)$ & $(-0.16)$ \\
\hline \multirow[t]{2}{*}{ Delta } & -0.0002 & 0.0006 & -0.0024 & 0.0042 & 0.0057 & -0.0059 \\
\hline & $(-0.09)$ & $(0.18)$ & $(-1.22)$ & $(1.11)$ & $(0.78)$ & $(-0.48)$ \\
\hline \multirow[t]{2}{*}{ Vega } & 0.0930 & -0.0832 & 0.0366 & 0.6783 & -0.9779 & $1.2427 *$ \\
\hline & $(0.62)$ & $(-0.14)$ & $(0.27)$ & $(1.24)$ & $(-0.99)$ & $(1.96)$ \\
\hline \multirow[t]{2}{*}{ S_Cash_Comp } & 0.4023 & 1.1605 & 0.0912 & 0.4677 & 0.8717 & 0.2632 \\
\hline & $(1.01)$ & $(1.46)$ & $(0.20)$ & $(0.56)$ & $(0.48)$ & $(0.32)$ \\
\hline \multirow[t]{2}{*}{ In_Wave } & $-1.7642 * * *$ & & & -0.4712 & & \\
\hline & $(-5.97)$ & & & $(-1.01)$ & & \\
\hline \multirow[t]{2}{*}{ Herding } & & $0.7565^{*}$ & & & 1.1834 & \\
\hline & & $(1.80)$ & & & $(1.53)$ & \\
\hline \multirow[t]{2}{*}{ Size } & -0.0600 & 0.1973 & -0.1332 & $-0.6991 * *$ & -0.4890 & $-0.7716^{* *}$ \\
\hline & $(-0.31)$ & $(0.36)$ & $(-0.84)$ & $(-2.24)$ & $(-0.67)$ & $(-2.45)$ \\
\hline \multirow[t]{2}{*}{ Payment_Cash } & $0.5463 * *$ & 0.5590 & $0.3875^{*}$ & 0.3430 & 0.0021 & 0.5093 \\
\hline & $(2.41)$ & $(1.17)$ & $(1.68)$ & $(1.01)$ & $(0.00)$ & $(1.32)$ \\
\hline \multirow[t]{2}{*}{ Diversifying } & -0.1254 & -0.1362 & -0.1077 & 0.3287 & 1.1527 & 0.0255 \\
\hline & $(-0.58)$ & $(-0.25)$ & $(-0.53)$ & $(0.96)$ & $(1.49)$ & $(0.07)$ \\
\hline \multirow[t]{2}{*}{ Runup } & -0.0331 & -0.0072 & -0.0077 & -0.3256 & -0.0533 & -0.4297 \\
\hline & $(-0.20)$ & $(-0.03)$ & $(-0.04)$ & $(-0.97)$ & $(-0.08)$ & $(-1.21)$ \\
\hline \multirow[t]{2}{*}{ Cash/Assets } & 0.0904 & -0.9983 & 0.3783 & $3.1478 *$ & 5.1015 & 2.1962 \\
\hline & $(0.09)$ & $(-0.48)$ & $(0.39)$ & $(1.94)$ & $(1.49)$ & $(1.31)$ \\
\hline \multirow[t]{2}{*}{ Public } & 0.1845 & -0.2306 & 0.2885 & 0.4378 & 0.0763 & 0.5452 \\
\hline & $(0.76)$ & $(-0.43)$ & $(1.10)$ & $(1.07)$ & $(0.09)$ & $(1.17)$ \\
\hline \multirow[t]{2}{*}{ Private } & -0.3653 & -0.3979 & $-0.4527^{*}$ & -0.0711 & $-1.4093 *$ & 0.3511 \\
\hline & $(-1.56)$ & $(-0.73)$ & $(-1.81)$ & $(-0.19)$ & $(-1.67)$ & $(0.86)$ \\
\hline \multirow[t]{2}{*}{ Relative_Size } & $1.5500 * * *$ & $1.8199 * *$ & $1.5439 * * *$ & $1.6880 * * *$ & 0.3691 & $1.9795 * * *$ \\
\hline & $(3.57)$ & $(2.02)$ & $(3.26)$ & $(3.79)$ & $(0.28)$ & $(4.08)$ \\
\hline \multirow[t]{2}{*}{$\mathrm{B} / \mathrm{M}$} & $3.9198 * * *$ & $4.7617 * * *$ & $3.3142 * * *$ & $2.4540 * * *$ & $3.5759 *$ & $2.2173 * *$ \\
\hline & $(5.94)$ & $(2.82)$ & $(6.37)$ & $(2.73)$ & $(1.79)$ & $(2.33)$ \\
\hline \multirow[t]{2}{*}{ Overvaluation } & 0.2833 & -0.7995 & $0.6399 * *$ & 0.2546 & 1.6627 & 0.0839 \\
\hline & $(1.10)$ & $(-1.22)$ & $(2.37)$ & $(0.56)$ & $(1.43)$ & $(0.19)$ \\
\hline
\end{tabular}

This article is protected by copyright. All rights reserved. 


\begin{tabular}{|c|c|c|c|c|c|c|}
\hline Sales_Shock & 0.0068 & -0.5334 & 0.0241 & -0.0294 & -0.4440 & -0.0281 \\
\hline & $(0.02)$ & $(-0.39)$ & $(0.08)$ & $(-0.06)$ & $(-0.25)$ & $(-0.05)$ \\
\hline Emp_Shock & 0.4247 & 1.4821 & 0.0435 & 0.2932 & $2.1322 *$ & 0.0229 \\
\hline & $(1.32)$ & $(1.43)$ & $(0.14)$ & $(0.58)$ & $(1.93)$ & $(0.04)$ \\
\hline Market_Volatility & 0.5732 & $-22.6436^{* *}$ & 2.4200 & 2.4656 & $24.3247 * *$ & -0.3322 \\
\hline & $(0.32)$ & $(-2.48)$ & $(1.34)$ & $(0.87)$ & $(2.07)$ & $(-0.12)$ \\
\hline Market Upswing & $-1.6081 * * *$ & $-4.8541 * * *$ & $-0.8592 * * *$ & 0.2075 & 0.1445 & 0.3716 \\
\hline & $(-5.62)$ & $(-5.40)$ & $(-3.11)$ & $(0.45)$ & $(0.11)$ & $(0.83)$ \\
\hline Prior_M\&A_Activity & 0.0413 & 0.0463 & 0.0147 & 0.5312 & 0.5608 & 0.4348 \\
\hline & $(0.20)$ & $(0.10)$ & $(0.07)$ & $(1.53)$ & $(0.72)$ & $(1.17)$ \\
\hline Distance & 0.0080 & -0.3229 & 0.1239 & -0.2051 & -0.3642 & -0.1308 \\
\hline & $(0.06)$ & $(-1.10)$ & $(0.99)$ & $(-1.07)$ & $(-0.81)$ & $(-0.65)$ \\
\hline Speed & 0.2695 & 1.3492 & 0.0436 & $-0.9856^{*}$ & -1.8866 & -0.7758 \\
\hline & $(0.85)$ & $(1.50)$ & $(0.13)$ & $(-1.79)$ & $(-1.45)$ & $(-1.39)$ \\
\hline No_Bidders & $0.7447^{*}$ & $1.6437 * *$ & 0.2952 & 1.0523 & 1.5722 & 0.9340 \\
\hline & $(1.79)$ & $(2.13)$ & $(0.60)$ & $(1.41)$ & $(0.91)$ & $(1.18)$ \\
\hline Number of Observations & 6,370 & 1,660 & 4,710 & 5,099 & 1,364 & 3,735 \\
\hline F-Statistic & $7.85^{* * *}$ & $4.64 * * *$ & $5.35 * * *$ & $2.47 * * *$ & 1.30 & $2.26^{* * *}$ \\
\hline R-Squared & 0.062 & 0.097 & 0.039 & 0.012 & 0.028 & 0.014 \\
\hline $\begin{array}{l}\text { Table 9: Standard devia } \\
\text { The table presents the nur } \\
\text { of cross-sectional acquisi } \\
\text { sample is } 10,684 \text { complet } \\
\text { Platinum. Stock price dat } \\
\text { trading days), 6-month (1 } \\
\text { returns. } S D \text { Tm_CARs is } \\
\text { over a T-month window } \\
\text { acquisition announcement } \\
\text { the cross-sectional standa } \\
\text { the acquisition effective d } \\
\text { respective time period. T } \\
\text { by Harford (2005). The re }\end{array}$ & $\begin{array}{l}\text { tion of cross } \mathbf{s} \\
\text { nber of acquis } \\
\text { ion returns ( } S \\
\text { ed U.S. acquis } \\
\text { are from CR } \\
26 \text { trading day } \\
\text { the cross-sect } \\
\text { sing the mark } \\
\text { Market retur } \\
\text { d deviation of } \\
\text { ate minus the } \\
\text { ansactions are } \\
\text { ported probab }\end{array}$ & $\begin{array}{l}\text { ctional bidd } \\
\text { tions initiatec } \\
\text { D_Tm_CARs } \\
\text { tions over th } \\
\text { SP. Cross-se } \\
\text { s), 9-month } \\
\text { onal standar } \\
\text { t model. The } \\
\text { s are based o } \\
\text { bidder's buy } \\
\text { puy-and-hold } \\
\text { classified as } \\
\text { lity statistics }\end{array}$ & $\begin{array}{l}\text { er's returns an } \\
\text { inside and out } \\
\text { and } S D \_T D_{-} A \\
\text { period January } \\
\text { tional standard } \\
189 \text { trading da } \\
\text { deviation of } t \\
\text { estimation per } \\
\text { a the CRSP val } \\
\text { and-hold daily } \\
\text { daily returns o } \\
\text { in-wave or ou } \\
2 * \operatorname{Pr}(\mathrm{F}<\mathrm{f})] \text { are }\end{array}$ & $\begin{array}{l}\text { erger wave } \\
\text { merger way } \\
P S M \text {, whe } \\
\text { 1993, to Dec } \\
\text { iations are } \\
\text { and } 12 \text {-mon } \\
\text { r's cumulat } \\
\text { is from } 200 \\
\text { veighted ind } \\
\text { ins over a } \\
\text { propensity- } \\
\text { wave follov } \\
\text { a the F-test }\end{array}$ & $\begin{array}{l}\text { S and standa } \\
\mathrm{T}=3,6,9 \\
\text { mber } 31,20 \\
\text { lculated for } \\
\text { ( } 252 \text { tradin } \\
\text { e abnormal } \\
\text { ays to } 60 \mathrm{da} \\
S D \_T m \_A \\
\text { month wind } \\
\text { core matche } \\
\text { g the meth } \\
\text { r difference }\end{array}$ & $\begin{array}{l}\text { deviations } \\
\text { or 12). The } \\
6 \text { from SDC } \\
\text {-month (63 } \\
\text { days) daily } \\
\text { aily returns } \\
\text { s before the } \\
\text { HR_PSM is } \\
\text { w following } \\
\text { firm for the } \\
\text { d developed } \\
\text { d variances. }\end{array}$ \\
\hline & In- & & Out-of-Wave & Difference & & -test \\
\hline $\begin{array}{c}\text { SD_3m_CARs } \\
\text { Observations }\end{array}$ & $\begin{array}{c}0.1 \\
3.1\end{array}$ & & $\begin{array}{c}0.1581 \\
6.855\end{array}$ & 0.0128 & & $\overline{0000}$ \\
\hline SD_6m_CARs & 0.2 & & 0.2228 & 0.0297 & & 0000 \\
\hline Observations & 3,1 & & 6,776 & & & \\
\hline SD_9m_CARs & 0.3 & & 0.2783 & 0.0434 & & 0000 \\
\hline Observations & 3,0 & & 6,735 & & & \\
\hline SD $12 \mathrm{~m}$ CARs & 0.3 & & 0.3231 & 0.0486 & & 0000 \\
\hline Observations & 3,0 & & 6,695 & & & \\
\hline SD_3m_ABHR_PSM & 0.2 & & 0.2290 & 0.0269 & & 0000 \\
\hline Observations & 2,3 & & 5,216 & & & \\
\hline SD_6m_ABHR_PSM & 0.3 & & 0.3265 & 0.0284 & & 0000 \\
\hline Observations & 2,2 & & 5,144 & & & \\
\hline SD_9m_ABHR_PSM & 0.4 & & 0.4086 & 0.0385 & & 0000 \\
\hline Observations & 2,2 & & 5,061 & & & \\
\hline SD $12 \mathrm{~m}$ ABHR PSM & 0.5 & & 0.4834 & 0.0479 & & 0000 \\
\hline Observations & 2,1 & & 4,992 & & & \\
\hline
\end{tabular}

This article is protected by copyright. All rights reserved. 
Table 10: Standard deviation of cross sectional bidder's returns, merger waves and CEO incentive compensation

The table presents the number of acquisitions initiated inside and outside merger waves and standard deviations of cross-sectional acquisition returns ( $S D_{-} T m_{-} C A R s$ and $S D_{-} T m_{-} A B H R s$, where $\mathrm{T}=3,6,9$, or 12). The sample is 10,684 completed U.S. acquisitions over the period January 1, 1993, to December 31, 2016 from SDC Platinum. Data on executive compensation are from ExecuComp and stock price data from CRSP. Crosssectional standard deviations are calculated for 3-month (63 trading days), 6-month (126 trading days), 9-month (189 trading days) and 12-month (252 trading days) daily returns. SD_Tm_CARs is the cross-sectional standard deviation of bidder's cumulative abnormal daily returns over a T-month window using the market model. The estimation period is from 200 days to 60 days before the acquisition announcement. Market returns are based on the CRSP value-weighted index. SD_Tm_ABHR_PSM is the cross-sectional standard deviation of bidder's buyand-hold daily returns over a T-month window following the acquisition effective date minus the buy-and-hold daily returns of the propensity-score matched firm for the respective time period. Delta is the dollar change in CEO's wealth for a 1 percent change in firm's stock price. Firms with Delta higher than the sample median are characterized as High Delta, otherwise they are characterized as Low Delta. Vega is the dollar change in CEO's wealth for a 1 percent change in the standard deviation of firm's stock returns. Firms with Vega higher than the sample median are characterized as High Vega, otherwise they are characterized as Low Vega. Transactions are classified as in-wave or out-of-wave following the method developed by Harford (2005). The reported probability statistics $[2 * \operatorname{Pr}(\mathrm{F}<\mathrm{f})]$ are from the $\mathrm{F}$-test for difference in variances.

\begin{tabular}{|c|c|c|c|c|c|c|c|c|c|}
\hline \multicolumn{10}{|c|}{ Panel A: Full Sample } \\
\hline & $\begin{array}{l}\text { Observ } \\
\text { ations }\end{array}$ & $\begin{array}{l}\text { High } \\
\text { Delta }\end{array}$ & $\begin{array}{l}\text { Low } \\
\text { Delta }\end{array}$ & $\begin{array}{c}\text { Differe } \\
\text { nce }\end{array}$ & $F$-test & $\begin{array}{l}\text { High } \\
\text { Vega }\end{array}$ & $\begin{array}{l}\text { Low } \\
\text { Vega }\end{array}$ & $\begin{array}{c}\text { Differe } \\
\text { nce }\end{array}$ & $F$-test \\
\hline $\begin{array}{l}\text { SD_3m_CAR } \\
\mathrm{s}\end{array}$ & 10,013 & 0.1600 & 0.1645 & -0.0045 & 0.0487 & 0.1571 & 0.1672 & -0.0100 & 0.0000 \\
\hline $\begin{array}{l}\text { SD_6m_CAR } \\
\text { s }\end{array}$ & 9,914 & 0.2318 & 0.2337 & -0.0019 & 0.5645 & 0.2245 & 0.2409 & -0.0164 & 0.0000 \\
\hline $\begin{array}{l}\text { SD_9m_CAR } \\
\text { s }\end{array}$ & 9,811 & 0.2932 & 0.2922 & 0.0010 & 0.8136 & 0.2828 & 0.3029 & -0.0201 & 0.0000 \\
\hline $\begin{array}{l}\text { SD_12m_CA } \\
\text { Rs }\end{array}$ & 9,701 & 0.3381 & 0.3402 & -0.0021 & 0.6591 & 0.3236 & 0.3551 & -0.0315 & 0.0000 \\
\hline $\begin{array}{l}\text { SD_3m_ABH } \\
\text { R PSM }\end{array}$ & 7,517 & 0.2360 & 0.2394 & -0.0034 & 0.3771 & 0.2326 & 0.2435 & -0.0109 & 0.0049 \\
\hline $\begin{array}{l}\text { SD_6m_ABH } \\
\text { R_PSM }\end{array}$ & 7,399 & 0.3310 & 0.3407 & -0.0097 & 0.0796 & 0.3245 & 0.3483 & -0.0238 & 0.0000 \\
\hline $\begin{array}{l}\text { SD_9m_ABH } \\
\text { R_PSM }\end{array}$ & 7,271 & 0.4153 & 0.4271 & -0.0118 & 0.0922 & 0.4075 & 0.4361 & -0.0286 & 0.0000 \\
\hline $\begin{array}{l}\text { SD_12m_AB } \\
\text { HR_PSM }\end{array}$ & 7,127 & 0.4896 & 0.5086 & -0.0191 & 0.0232 & 0.4780 & 0.5218 & -0.0438 & 0.0000 \\
\hline \multicolumn{10}{|c|}{ Panel B: In-Wave } \\
\hline & $\begin{array}{l}\text { Observ } \\
\text { ations }\end{array}$ & $\begin{array}{l}\text { High } \\
\text { Delta }\end{array}$ & $\begin{array}{l}\text { Low } \\
\text { Delta }\end{array}$ & $\begin{array}{c}\text { Differe } \\
\text { nce }\end{array}$ & $F$-test & $\begin{array}{l}\text { High } \\
\text { Vega }\end{array}$ & $\begin{array}{l}\text { Low } \\
\text { Vega }\end{array}$ & $\begin{array}{c}\text { Differe } \\
\text { nce }\end{array}$ & $F$-test \\
\hline $\begin{array}{l}\text { SD_3m_CAR } \\
\mathrm{s}\end{array}$ & 3,158 & 0.1722 & 0.1694 & 0.0028 & 0.5163 & 0.1752 & 0.1668 & 0.0084 & 0.0509 \\
\hline $\begin{array}{l}\text { SD_6m_CAR } \\
\text { s }\end{array}$ & 3,138 & 0.2541 & 0.2508 & 0.0033 & 0.6114 & 0.2556 & 0.2498 & 0.0057 & 0.3707 \\
\hline $\begin{array}{l}\text { SD_9m_CAR } \\
\text { S }\end{array}$ & 3,076 & 0.3263 & 0.3163 & 0.0100 & 0.2231 & 0.3236 & 0.3194 & 0.0042 & 0.6121 \\
\hline $\begin{array}{l}\text { SD_12m_CA } \\
\text { Rs }\end{array}$ & 3,006 & 0.3721 & 0.3714 & 0.0007 & 0.9403 & 0.3654 & 0.3777 & -0.0123 & 0.1992 \\
\hline $\begin{array}{l}\text { SD_3m_ABH } \\
\text { R_PSM }\end{array}$ & 2,301 & 0.2588 & 0.2516 & 0.0072 & 0.3493 & 0.2519 & 0.2603 & -0.0084 & 0.2672 \\
\hline $\begin{array}{l}\text { SD_6m_ABH } \\
\text { R_PSM }\end{array}$ & 2,255 & 0.3588 & 0.3493 & 0.0095 & 0.3814 & 0.3519 & 0.3577 & -0.0057 & 0.5865 \\
\hline $\begin{array}{l}\text { SD_9m_ABH } \\
\text { R_PSM }\end{array}$ & 2,210 & 0.4471 & 0.4473 & -0.0001 & 0.9881 & 0.4283 & 0.4656 & -0.0373 & 0.0056 \\
\hline
\end{tabular}

This article is protected by copyright. All rights reserved. 


\begin{tabular}{|c|c|c|c|c|c|c|c|c|c|}
\hline $\begin{array}{l}\text { SD_12m_AB } \\
\text { HR_PSM }\end{array}$ & 2,135 & 0.5253 & 0.5404 & -0.0151 & 0.3630 & 0.5068 & 0.5545 & -0.0478 & 0.0033 \\
\hline \multicolumn{10}{|c|}{ Panel C: Out-of-Wave } \\
\hline & $\begin{array}{l}\text { Observ } \\
\text { ations }\end{array}$ & $\begin{array}{l}\text { High } \\
\text { Delta }\end{array}$ & $\begin{array}{l}\text { Low } \\
\text { Delta }\end{array}$ & $\begin{array}{c}\text { Differe } \\
\text { nce }\end{array}$ & $F$-test & $\begin{array}{l}\text { High } \\
\text { Vega }\end{array}$ & $\begin{array}{l}\text { Low } \\
\text { Vega }\end{array}$ & $\begin{array}{c}\text { Differe } \\
\text { nce }\end{array}$ & $F$-test \\
\hline $\begin{array}{l}\text { SD_3m_CAR } \\
\text { s }\end{array}$ & 6,855 & 0.1535 & 0.1625 & -0.0090 & 0.0009 & 0.1488 & 0.1674 & -0.0185 & 0.0000 \\
\hline $\begin{array}{l}\text { SD_6m_CAR } \\
\text { s }\end{array}$ & 6,776 & 0.2195 & 0.2259 & -0.0064 & 0.0964 & 0.2099 & 0.2359 & -0.0260 & 0.0000 \\
\hline $\begin{array}{l}\text { SD_9m_CAR } \\
\text { s }\end{array}$ & 6,735 & 0.2749 & 0.2810 & -0.0061 & 0.2005 & 0.2637 & 0.2930 & -0.0293 & 0.0000 \\
\hline $\begin{array}{l}\text { SD_12m_CA } \\
\text { Rs }\end{array}$ & 6,695 & 0.3196 & 0.3256 & -0.0060 & 0.2831 & 0.3041 & 0.3424 & -0.0383 & 0.0000 \\
\hline $\begin{array}{l}\text { SD_3m_ABH } \\
\text { R_PSM }\end{array}$ & 5,216 & 0.2237 & 0.2348 & -0.0110 & 0.0141 & 0.2241 & 0.2351 & -0.0111 & 0.0143 \\
\hline $\begin{array}{l}\text { SD_6m_ABH } \\
\text { R_PSM }\end{array}$ & 5,144 & 0.3163 & 0.3375 & -0.0212 & 0.0100 & 0.3127 & 0.3435 & -0.0309 & 0.0000 \\
\hline $\begin{array}{l}\text { SD_9m_ABH } \\
\text { R PSM }\end{array}$ & 5,061 & 0.3987 & 0.4195 & -0.0208 & 0.0108 & 0.3988 & 0.4210 & -0.0222 & 0.0068 \\
\hline $\begin{array}{l}\text { SD_12m_AB } \\
\text { HR PSM }\end{array}$ & 4,992 & 0.4714 & 0.4968 & -0.0254 & 0.0088 & 0.4657 & 0.5055 & -0.0398 & 0.0000 \\
\hline
\end{tabular}

\section{Appendix A: Variable definitions}

\begin{tabular}{|l|l|}
\hline \multicolumn{2}{|l|}{ Compensation Variables } \\
\hline Delta & $\begin{array}{l}\text { The dollar change in CEO's wealth for a 1 percent change in the firm's stock price } \\
\text { from ExecuComp. }\end{array}$ \\
\hline Vega & $\begin{array}{l}\text { The dollar change in CEO's wealth for a 1 percent change in the standard deviation of } \\
\text { the firm's stock returns from ExecuComp. }\end{array}$ \\
\hline Cash_Comp & The sum of salary and bonus payments to the CEO from ExecuComp. \\
\hline New_Grants & $\begin{array}{l}\text { The sum of the Black-Scholes fair value of new option and stock grants to the CEO } \\
\text { from ExecuComp. }\end{array}$ \\
\hline Total_Comp & $\begin{array}{l}\text { The sum of CEO's salary, bonus, new stock and option grants and other forms of } \\
\text { compensation from ExecuComp. }\end{array}$ \\
\hline S_Cash_Comp & $\begin{array}{l}\text { CEO's cash compensation (salary and bonus) standardized by total compensation from } \\
\text { ExecuComp. }\end{array}$ \\
\hline Size & $\begin{array}{l}\text { The logarithm of book value of total assets at the end of the year preceding the } \\
\text { acquisition announcement from Compustat. }\end{array}$ \\
\hline Runup & $\begin{array}{l}\text { The acquirer's buy-and-hold daily returns between 205 days and 6 days before the } \\
\text { acquisition announcement date minus the buy-and-hold daily returns of the propensity- } \\
\text { score matched firm for the same time period from CRSP. }\end{array}$ \\
\hline Past_ABHR & $\begin{array}{l}\text { The market-adjusted buy-and-hold daily returns of the firm for the calendar year from } \\
\text { CRSP. Market returns are from the CRSP value-weighted index. }\end{array}$ \\
\hline Cash/Assets & Cash and cash equivalents to book value of total assets from Compustat. \\
\hline B/M & The book value of equity from Compustat divided by its market value from CRSP. \\
\hline ROA & $\begin{array}{l}\text { The operating income before depreciation divided by book value of total assets from } \\
\text { Compustat. }\end{array}$ \\
\hline Sales_Growth & $\begin{array}{l}\text { The natural logarithm of the ratio of sales in year t to sales in the previous year (t-1) } \\
\text { from Compustat. }\end{array}$ \\
\hline Leverage & Total debt to total assets from Compustat. \\
\hline P/E & The ratio of the stock price to earnings per share from CRSP/Compustat. \\
\hline NC_Working_Cap & $\begin{array}{l}\text { Current assets minus current liabilities minus cash and cash equivalents standardized } \\
\text { by book value of total assets from Compustat. }\end{array}$ \\
\hline Prior_M\&A_Activity & A dummy variable that takes the value of one if the firm has been engaged in M\&A \\
\hline
\end{tabular}

This article is protected by copyright. All rights reserved. 


\begin{tabular}{|c|c|}
\hline & activity as bidder or target in the previous year and zero otherwise from SDC Platinum. \\
\hline Frequent & $\begin{array}{l}\text { A dummy variable that takes the value of one if the acquirer has made at least five } \\
\text { acquisitions over any three-year window surrounding the transaction and zero } \\
\text { otherwise (combined sample). A dummy variable that takes the value of one if the firm } \\
\text { has made at least five acquisitions over any three-year window surrounding the fiscal } \\
\text { year-end and zero otherwise (ExecuComp sample). }\end{array}$ \\
\hline & Merger Performance Measures \\
\hline $\operatorname{CARs}(0,1)$ & $\begin{array}{l}\text { The bidder's cumulative abnormal returns over a two-day event window }(0,+1) \text { where } \\
0 \text { is the acquisition announcement date using the market model. The estimation period } \\
\text { is from } 200 \text { days to } 60 \text { days before the acquisition announcement. Market returns are } \\
\text { based on the CRSP value-weighted index. }\end{array}$ \\
\hline $2 y A B H R$ & $\begin{array}{l}\text { The bidder's 2-year buy-and-hold daily returns following the acquisition effective date } \\
\text { minus the 2-year buy-and-hold daily returns of the matched firm for the same time } \\
\text { period from CRSP. }\end{array}$ \\
\hline $2 y A B H R \_P S M$ & $\begin{array}{l}\text { The bidder's 2-year buy-and-hold daily returns following the acquisition effective date } \\
\text { minus the } 2 \text {-year buy-and-hold daily returns of the propensity-score matched firm for } \\
\text { the same time period from CRSP. }\end{array}$ \\
\hline D_ROA & $\begin{array}{l}\text { The difference between the acquirer's return on assets (ROA) at the end of the second } \\
\text { year following the effective date }(\mathrm{t}+2) \text { and the acquirer's ROA at the year of the } \\
\text { acquisition effective date }(\mathrm{t}) \text { from Compustat. }\end{array}$ \\
\hline$D_{-} R O A \_P S M$ & $\begin{array}{l}\text { The difference between the acquirer's return on assets (ROA) at the end of the second } \\
\text { year following the effective date }(t+2) \text { and the acquirer's ROA at the year of the } \\
\text { acquisition effective date }(t) \text { minus the change in ROA of the propensity-score } \\
\text { matched firm for the same time period from Compustat. }\end{array}$ \\
\hline & Cross-Sectional Volatility Measures \\
\hline$S D \_3 m_{-} C A R s$ & $\begin{array}{l}\text { The cross-sectional standard deviation of acquirers' cumulative abnormal daily returns } \\
\text { for a } 3 \text {-month window ( } 63 \text { trading days) beginning one day after the acquisition } \\
\text { announcement date. The variable is repeated over 6-month, 9-month and 12-month } \\
\text { windows following the announcement date. }\end{array}$ \\
\hline$S D \_3 m_{-} A B H R s \_P S M$ & $\begin{array}{l}\text { The cross-sectional standard deviation of acquirers' abnormal buy-and-hold daily } \\
\text { returns for a 3-month period ( } 63 \text { trading days) beginning one day after the acquisition } \\
\text { effective date. Abnormal buy-and-hold returns are calculated against the propensity- } \\
\text { score matched firm. The variable is repeated over } 6 \text {-month, 9-month and 12-month } \\
\text { windows following the effective date. }\end{array}$ \\
\hline & Deal Characteristics \\
\hline In-Wave & $\begin{array}{l}\text { A dummy variable that takes the value of one if the acquisition has been initiated during } \\
\text { a merger wave and zero otherwise. Transactions are classified as in-wave or out-of- } \\
\text { wave following the method developed by Harford (2005). }\end{array}$ \\
\hline In-Wave_Year & $\begin{array}{l}\text { A dummy variable that takes the value of one if the industry experiences a merger } \\
\text { wave during the calendar year and zero otherwise. }\end{array}$ \\
\hline Acquisition & $\begin{array}{l}\text { A dummy variable that takes the value of one if a firm has made an acquisition } \\
\text { announcement in a given year and zero otherwise. }\end{array}$ \\
\hline Payment_Cash & $\begin{array}{l}\text { A dummy variable that takes the value of one if the transaction is financed only with } \\
\text { cash and zero otherwise. }\end{array}$ \\
\hline Diversifying & $\begin{array}{l}\text { A dummy variable that takes the value of one if the acquiring firm and the target } \\
\text { operate in different industries and zero otherwise based on the Fama and French (1997) } \\
\text { classification of } 48 \text { industries. }\end{array}$ \\
\hline Public & $\begin{array}{l}\text { A dummy variable that takes the value of one if the target is a publicly listed firm and } \\
\text { zero otherwise. }\end{array}$ \\
\hline Private & $\begin{array}{l}\text { A dummy variable that takes the value of one if the target is a privately held firm and } \\
\text { zero otherwise. }\end{array}$ \\
\hline Relative_Size & $\begin{array}{l}\text { The ratio of the deal value reported in SDC Platinum to the market value of the } \\
\text { acquiring firm } 4 \text { weeks before the acquisition announcement date from CRSP. }\end{array}$ \\
\hline Distance & $\begin{array}{l}\text { The geographic distance in miles between the headquarters of the acquirer and the } \\
\text { target at the time of the acquisition announcement from SDC Platinum. }\end{array}$ \\
\hline Speed & $\begin{array}{l}\text { The elapsed time (in years) between the acquisition announcement date and the } \\
\text { effective date from SDC Platinum. }\end{array}$ \\
\hline No_Bidders & The number of firms bidding for a target during a deal from SDC Platinum. \\
\hline
\end{tabular}

This article is protected by copyright. All rights reserved. 


\begin{tabular}{|l|l|}
\hline Herding & $\begin{array}{l}\text { A dummy variable that take the value of one if a deal has been initiated during the } \\
\text { second half of a merger wave and zero otherwise (in-wave deals only). }\end{array}$ \\
\hline \multicolumn{3}{|c|}{ Industry \& Market Characteristics } \\
\hline Overvaluation & $\begin{array}{l}\text { A dummy variable that takes the value of one if the median Market-to-Book value of } \\
\text { the firm's industry is higher than the industry's five-year moving average and zero } \\
\text { otherwise (Duchin and Schmidt, 2013) from Compustat. }\end{array}$ \\
\hline $\begin{array}{l}\text { The difference between an industry's sales growth over a three-year window and the } \\
\text { average sales growth of all industries for the same period. (Mitchell and Mulherin, } \\
\text { 1996). Industries are defined according to the Fama and French (1997) classification of } \\
\text { 48 industries. Sales growth is defined as the natural logarithm of the ratio of an } \\
\text { industry's sales in year } t \text { to its sales in year t-3 from Compustat. }\end{array}$ \\
\hline Emp_Shock & $\begin{array}{l}\text { The difference between an industry's employment growth over a three-year window } \\
\text { and the average employment growth of all industries for the same period. (Mitchell } \\
\text { and Mulherin, 1996). Industries are defined according to the Fama and French (1997) } \\
\text { classification of 48 industries. Employment growth is defined as the natural logarithm } \\
\text { of the ratio of an industry's number of employees in year t to its number of employees } \\
\text { in year t-3 from Compustat. } \\
\text { The annualized standard deviation of the CRSP value-weighted index in a given year. }\end{array}$ \\
\hline Market_Volatility & $\begin{array}{l}\text { A dummy variable that takes the value of one if the annualized market return using the } \\
\text { average daily market return over the calendar year is higher than the risk-free rate and } \\
\text { zero otherwise. Market returns are based on the CRSP value-weighted index. }\end{array}$ \\
\hline Market_Upswing
\end{tabular}

\section{Appendix B: Distribution of merger waves across industries and time}

The table presents the distribution of 94 merger waves for the Fama and French (1997) 48 industry classifications across time. Merger waves last for two years and are identified based on the method developed by Harford (2005) for a sample of 41,557 completed U.S. acquisitions from SDC Platinum over the period January 1, 1981 to December 31, 2016.

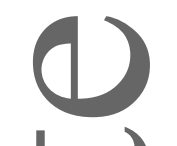

\begin{tabular}{|c|c|c|c|c|c|c|c|c|}
\hline \multirow[b]{2}{*}{ Industry } & \multicolumn{2}{|c|}{ 1981-1990 } & \multicolumn{2}{|c|}{ 1991-2000 } & \multicolumn{2}{|c|}{ 2001-2010 } & \multicolumn{2}{|c|}{ 2011-2016 } \\
\hline & $\begin{array}{l}\text { Start of } \\
\text { Wave }\end{array}$ & $\begin{array}{l}\text { No of } \\
\text { bids }\end{array}$ & $\begin{array}{l}\text { Start of } \\
\text { Wave }\end{array}$ & $\begin{array}{l}\text { No of } \\
\text { bids }\end{array}$ & $\begin{array}{l}\text { Start of } \\
\text { Wave }\end{array}$ & $\begin{array}{l}\text { No of } \\
\text { bids }\end{array}$ & $\begin{array}{l}\text { Start of } \\
\text { Wave }\end{array}$ & $\begin{array}{l}\text { No of } \\
\text { bids }\end{array}$ \\
\hline Agriculture & & & Feb-96 & 28 & & & Oct-13 & 26 \\
\hline Aircraft & Jul-83 & 25 & Sep-97 & 37 & & & & \\
\hline $\begin{array}{l}\text { Alcoholic } \\
\text { Beverages }\end{array}$ & & & & & & & & \\
\hline Apparel & & & & & Nov-04 & 43 & Jul-13 & 22 \\
\hline $\begin{array}{l}\text { Automobiles } \\
\text { and Trucks }\end{array}$ & & & Jun-96 & 77 & & & & \\
\hline Banking & Apr-82 & 356 & Nov-96 & 678 & Jul-03 & 343 & Jan-14 & 260 \\
\hline $\begin{array}{l}\text { Business } \\
\text { Services }\end{array}$ & Jan-89 & 165 & Sep-98 & 1,494 & Jan-01 & 819 & Jun-13 & 419 \\
\hline $\begin{array}{l}\text { Business } \\
\text { Supplies }\end{array}$ & & & Jul-97 & 54 & & & & \\
\hline Candy and Soda & & & & & & & Feb-13 & 14 \\
\hline Chemicals & Jan-83 & 47 & Aug-97 & 88 & & & & \\
\hline Coal & & & & & Feb-05 & 28 & & \\
\hline Computers & & & Apr-98 & 332 & Jan-01 & 183 & Jan-11 & 79 \\
\hline Construction & Oct- 82 & 27 & Dec-96 & 110 & & & Jul-14 & 45 \\
\hline $\begin{array}{l}\text { Construction } \\
\text { Materials }\end{array}$ & Feb-83 & 67 & Aug-96 & 114 & Sep-04 & 66 & & \\
\hline $\begin{array}{l}\text { Consumer } \\
\text { Goods }\end{array}$ & Jun-83 & 55 & Jan-97 & 86 & & & & \\
\hline Defense & & & Dec-96 & 19 & & & & \\
\hline $\begin{array}{l}\text { Electrical } \\
\text { Equipment }\end{array}$ & & & & & & & & \\
\hline $\begin{array}{l}\text { Electronic } \\
\text { Equipment }\end{array}$ & Nov-82 & 76 & Dec-98 & 434 & Feb-01 & 254 & & \\
\hline Entertainment & & & Oct-96 & 155 & & & Apr-12 & 34 \\
\hline
\end{tabular}

This article is protected by copyright. All rights reserved. 


\begin{tabular}{|c|c|c|c|c|c|c|c|c|}
\hline $\begin{array}{l}\text { Fabricated } \\
\text { Products }\end{array}$ & & & Apr-96 & 36 & & & & \\
\hline Food Products & & & Jul-97 & 63 & Dec- -05 & 42 & Aug-13 & 39 \\
\hline Healthcare & Jan-83 & 81 & Jan-96 & 324 & Dec-04 & 136 & Oct-13 & 123 \\
\hline Insurance & & & Jun-96 & 157 & Oct-01 & 87 & Oct-13 & 53 \\
\hline Machinery & & & Sep-96 & 215 & Jan-06 & 111 & & \\
\hline $\begin{array}{l}\text { Measuring and } \\
\text { Control Equip }\end{array}$ & Jan-83 & 48 & Dec-95 & 109 & & & & \\
\hline $\begin{array}{l}\text { Medical } \\
\text { Equipment }\end{array}$ & & & May-95 & 158 & Dec-04 & 135 & & \\
\hline \multicolumn{9}{|l|}{ Miscellaneous } \\
\hline \multicolumn{9}{|l|}{$\begin{array}{l}\text { Nonmetallic } \\
\text { Mining }\end{array}$} \\
\hline $\begin{array}{l}\text { Personal } \\
\text { Services } \\
\end{array}$ & & & Jan-97 & 102 & & & & \\
\hline $\begin{array}{l}\text { Petroleum and } \\
\text { Natural Gas }\end{array}$ & Jan-83 & 117 & Jun-96 & 291 & Jan-06 & 246 & Nov-12 & 163 \\
\hline $\begin{array}{l}\text { Pharmaceutical } \\
\text { Products }\end{array}$ & & & Jun-98 & 124 & & & & \\
\hline \multicolumn{9}{|l|}{ Precious Metals } \\
\hline $\begin{array}{l}\text { Printing and } \\
\text { Publishing }\end{array}$ & & & Jun-97 & 61 & & & Dec-13 & 30 \\
\hline Real Estate & Mar-83 & 42 & Feb-97 & 694 & Jan-05 & 195 & Oct-12 & 248 \\
\hline $\begin{array}{l}\text { Recreational } \\
\text { Products }\end{array}$ & & & Nov-96 & 53 & Sep-02 & 31 & & \\
\hline $\begin{array}{l}\text { Restaurants, } \\
\text { Hotel, Motel }\end{array}$ & Feb-83 & 46 & Jul-96 & 366 & Feb-05 & 118 & & \\
\hline Retail & & & Sep-96 & 283 & May-05 & 124 & & \\
\hline $\begin{array}{l}\text { Rubber and } \\
\text { Plastic Products }\end{array}$ & & & Aug-97 & 53 & Apr-01 & 29 & & \\
\hline $\begin{array}{l}\text { Shipbuilding, } \\
\text { Railroad Eq }\end{array}$ & & & Jul-97 & 16 & & & & \\
\hline \multicolumn{9}{|l|}{$\begin{array}{l}\text { Shipping } \\
\text { Containers }\end{array}$} \\
\hline $\begin{array}{l}\text { Steel Works, } \\
\text { Etc. }\end{array}$ & Apr-82 & 33 & May-96 & 81 & & & & \\
\hline $\begin{array}{l}\text { Telecommunica } \\
\text { tions }\end{array}$ & Apr-82 & 97 & Aug-98 & 417 & Jan-01 & 186 & & \\
\hline \multicolumn{9}{|l|}{ Textiles } \\
\hline \multicolumn{9}{|l|}{$\begin{array}{l}\text { Tobacco } \\
\text { Products }\end{array}$} \\
\hline Trading & Feb-82 & 252 & Nov-96 & 1,107 & Apr-05 & 588 & Aug-13 & 515 \\
\hline Transportation & & & Sep-96 & 166 & Dec-05 & 94 & Aug-13 & 105 \\
\hline Utilities & Jan-89 & 59 & Dec-96 & 235 & & & Aug-13 & 107 \\
\hline Wholesale & Jun-83 & 82 & Dec-96 & 408 & Jun-05 & 148 & & \\
\hline
\end{tabular}

This article is protected by copyright. All rights reserved. 